\title{
A computable general equilibrium analysis of Brexit: Barriers to trade and immigration restrictions
}

\author{
Gabriela Ortiz Valverde $^{1,2}$ (iD | Maria C. Latorre ${ }^{1}$ (D) \\ ${ }^{1}$ Department of Applied \& Structural Economics \& History, Facultad de Estudios Estadisticos, Universidad Complutense de \\ Madrid, Madrid, Spain \\ ${ }^{2}$ Escuela de Economía, Facultad Ciencias Sociales, Universidad Nacional de Costa Rica, Heredia, Costa Rica
}

\section{K E Y W O R D S}

ad valorem equivalents, migration, most favoured nation, non-tariff barriers, tariffs

\section{1 | INTRODUCTION}

The United Kingdom's withdrawal from the European Union has raised concerns about its potential impact on the living standards in both regions. The exit of the UK from the EU single market will necessarily lead to restrictions on trade and migration between the UK and the EU. According to the majority of economic studies, this will reduce trade, production and welfare (see Busch \& Matthes, 2016; Fernández-Pacheco Theurer, López, \& Latorre, 2018; Latorre, Olekseyuk, \& Yonezawa, 2019 for reviews).

The exit of the UK from the EU has been surrounded by uncertainty. The Withdrawal Agreement (WA) negotiated by the then Prime Minister (PM) Theresa May, which was approved by the 27 EU leaders on November 2018, was rejected three times by the UK's parliament. The main issue in the discussion was the 'backstop' provision for Northern Ireland (NI).

Theresa May resigned on May 24 (2019). She was substituted by Boris Johnson, who was elected as the new UK's PM on July 24 (2019). With him, a new WA proposal has been born, which seeks to remove the 'backstop' provision from the deal and allow the UK to take control of its regulatory affairs and trade policy. Under this new WA, if the UK and EU do not agree on a new future relationship deal at the end of the transition period, an open border between NI and Ireland will be maintained. However, NI will apply many EU regulations and there will be a customs border between the UK and the NI in the Irish Sea. The rest of the UK will not be subject to EU regulations and will not form part of the EU customs union.

The political declaration released together with Johnson's WA states that the future relationship with the EU should be based on an FTA, which ensures no tariffs, fees, charges or quantitative restrictions across sectors. Its disciplines on Technical Barriers to Trade and Sanitary and Phyto-sanitary controls and 
services liberalization should be based on and go beyond the World Trade Organization arrangements. Nevertheless, this declaration is not politically binding.

Although the new WA and its Political Declaration were approved by the European Council on 17 October (2019), the UK Parliament wanted more time to be able to ratify it. As a result, the UK asked for a further extension of the Brexit deadline until 31 January 2020, which the EU has accepted. This was due to the fact that a new departure date of October 31 (2019) had been set in case no WA was approved by that date. Boris Johnson has called for an early election for December 12 and the Parliament has voted in favor. If he gets a stronger weigh in Parliament, he may be able to obtain the approval for his WA agreement.

In this paper, we evaluate the impact of Brexit along two dimensions: barriers to trade and restrictions to migration. Most of the previous studies have focused on trade (e.g. Aichele, Felbermayr, Petersen, \& Schoof, 2015; Booth, Howarth, Persson, Ruparel, \& Swidlicki, 2015; Dhingra et al., 2017; Dhingra, Ottaviano, Sampson, \& Reenen, 2016; Minford, Gupta, Mai, Mahambare, \& Xu, 2007; Ottaviano, Pessoa, Sampson, \& Reenen, 2014). Other studies concentrate on the effects of migration and capital movement in the UK. However, they do not include trade (e.g. Oxford Economics, 2016; Dustman \& Frattini, 2014 and Di Giovanni, Levchenko, \& Ortega, 2015). By contrast, Ciuriak, Dadkhah, and Xiao (2017) and Latorre, Olekseyuk, and Yonezawa (2018) include trade and foreign direct investment (FDI) but not immigration. Finally, Kierzenkowski, Paini, Rusticelli, and Zwarti (2016), Jafari and Britz (2018) and PricewaterhouseCoopers PwC (2016) include trade and migration (among other elements), as we do.

In comparison to Kierzenkowski et al. (2016) and PwC (2016), our study provides results not only for macroeconomic aggregates but also the impact across 21 sectors in the UK economy. Moreover, unlike Kierzenkowski et al. (2016), we analyse the effects of Brexit in trade and migration in turn. This allows us to identify their contribution in isolation. On the other hand, PwC (2016) simulates the entry of skilled workers, which, they argue would increase due to a small liberalisation in visa requirements in the UK. By contrast, we estimate the impacts of restrictions on both skilled and unskilled workers separately. Our approach takes into account the conditions agreed in the WA approved by EU leaders on 25 November 2018. This agreement did not specify any preferential condition for skilled workers. In addition, according to Szary and McEnaney (2018), there are signs that the Brexit vote may have already significantly slowed the influx of foreign workers. The decline reflects both fewer EU citizens arriving in the country and more leaving.

We also run a scenario in which the UK eliminates all tariffs with respect to all its trading partners. This setting has received less attention in the literature. Only Dhingra et al. (2017) and Minford, Gupta, Le Mai, Mahambare, and Xu (2015) estimate it. Interestingly, while Dhingra et al. (2017) obtain that its impact is very small, Minford et al. (2015) argue that the UK would experience a $4 \%$ rise in welfare. According to Minford et al. (2015), the rise of trade with other regions would by far compensate the losses of trade with the EU under the World Trade Organization (WTO) conditions. Their estimates have been criticised because they assume that the UK's prices of manufactures and agricultural goods would fall by $10 \%$ after Brexit and that trade flows would respond disproportionately heavily to trade costs (for more details, see Sampson, Dhingra, Ottaviano, \& Reenen, 2016 and Latorre et al., 2018). As Dhingra et al. (2017), we also derive that the unilateral tariff elimination would have a very small impact. By contrast, the negative trade outcomes we obtain from non-tariff barriers (NTBs) surpass, by far, the ones derived by Dhingra et al. (2017). This is of particular interest given the fact that we also employ a static, ${ }^{1}$ general equilibrium approach in a perfectly com-

\footnotetext{
${ }^{1}$ Dhingra et al. (2017) also estimate the dynamic losses from Brexit, which triple the ones from the static framework, using a reduced-form model. According to Gancía (2017, p. 694) in general "the reduced-form approach suffers from well-known identification issues".
} 
petitive setting with a comprehensive input-output structure (i.e. with imported intermediates and sectoral linkages) and the same barriers that Dhingra et al. (2017) use. The difference between both approaches lies is the fact that Dhingra et al. (2017) run a new quantitative trade model (NQTM) based on structural gravity and we use a standard computable general equilibrium (CGE), namely, the Global Trade Analysis Project (GTAP) model. Both are multiregional and multisectoral models, although the number of sectors and regions differ between them. Dhingra et al. (2017) have 35 sectors and 40 regions and our CGE features 21 sectors and 5 regions.

In the model of Dhingra et al. (2017) the impact of Brexit takes place through trade, which is determined by structural gravity type variables, including national income, distance, technology (which is only based on wages) and trade obstacles such as tariff and NTBs. ${ }^{2}$ By contrast, in our CGE model Armington functions govern the shares of expenditures allocated to domestically produced or imported goods, together with trade barriers, consumers' preferences and technology. Dhingra et al. (2017), and NQTMs in general, obtain most of their structural parameters directly from the same database with which they conduct their simulations. ${ }^{3}$ This contrasts with CGEs in which more structural parameters need to be taken from the literature, partly because the CGE is more detailed with respect to production functions and preferences. In fact, the GTAP model incorporates more realistic features and data of the economies, such as the real trade imbalances, several factors of production and heterogeneous NTBs across sectors. By contrast, Dhingra et al. (2017, p. 668) assume that trade is balanced, model only one factor of production and their NTBs increase "uniformly to UK-EU trade in all sectors of the economy." The complexity and richness of CGEs models allows us to introduce not only trade but also migration, making the results more comparable than if they are obtained with different models. 4

Caliendo and Parro (2015, pp. 2-3) say that: "adding detail into a model comes at the cost of losing track of the mechanisms that deliver the main results" and that the structural gravity model "simulations are performed with few data and parameter requirements." Costinot and Rodríguez-Clare (2014, p. 198) point out that "NQTMs put more emphasis on transparency than on realism." Balistreri and Tarr (2017) highlight that CGEs provide analysis on levels, contrasting to the percentage changes of NQTMs. Therefore, CGEs fully capture the benchmark and counterfactual data. "In this way, all the data from the benchmark accounts can be used and results important to policymakers, such as output changes by sector and relative factor prices can be easily extracted" (Balistreri \& Tarr 2017, p. 23). Thus, our CGE approach allows us to offer a very detailed assessment of the impact of Brexit for a rich

\footnotetext{
${ }^{2}$ This approach has been criticized on the grounds that past trade flows may not predict well future trade flows (Thomas, 2015; Wagner, 2015). This problem may be particularly relevant in the case of Brexit, since this phenomenon has no precedents and trade data may be missing effects that only appear in a disintegration process.

${ }^{3}$ Gancía (2017) suggests that Dhingra et al. (2017) should have estimated the value of the trade elasticity, which plays a central role in their approach, at least for UK sectors. He explains that there is no consensus in the literature regarding the value of this elasticity, while Melitz and Redding (2015) point out that its value may not be constant, which would challenge the analysis of Dhingra et al. (2017).

${ }^{4}$ Some of the authors in the paper of Dhingra et al. (2017) have also worked on the impact of Brexit on migration in Wadsworth et al. (2016). This latter paper forms part of a book comprising a broad analysis of Brexit, elaborated by the Centre for Economic Performance (2016). In contrast with the analysis of trade provided in the book, which is included in a technical paper and is the predecessor of Dhingra et al. (2017), for migration no general equilibrium modelling exercise is carried out. Wadsworth et al. (2016) provides a detailed, but mostly descriptive, analysis on migration. This same comment applies to the accompanying technical paper of Wadsworth et al. (2016), which is also included in the book and to Wadsworth $(2015 ; 2017 \mathrm{a} ; 2017 \mathrm{~b})$. Although in the technical papers some correlations are included, like the ones between EU immigration and the UK-born unemployment rate and wages, suggesting no statistically significant relationship (negative or positive), descriptive data are their main focus.
} 
set of micro and macroeconomic variables, which extends the results of most of the previous available studies of Brexit.

Apart from providing new estimations for the impact of trade and migration restrictions related to Brexit, another contribution of this paper is that we compare the results of an econometric (NQTMs) approach with a computational (CGE) model. In particular, we compare the outcomes of the most influential and widely cited model of Brexit (Dhingra et al., 2017) with a standard, well-known and extensively used CGE, namely, the GTAP model. ${ }^{5}$

The rest of the paper is organised as follows. The next section explains the model and the simulations. Section 3 describes the data used for our approach. In the results section, we depict the macro and microeconomic quantitative effects of Brexit. That leads to the final section, in which we present some concluding remarks. Two appendixes close the paper. One explains the origin of data on EU migrants' skill levels and the other one carries out a sensitivity analysis.

\section{2 | THE MODEL AND SIMULATIONS}

There are several ways through which the UK's exit from the EU could result in economic impacts. In this paper, we focus on two dimensions: trade and migration. As noted in the introduction, our study is conducted by means of a well-known CGE, namely, the GTAP model. CGE models have the ability to capture the interactions among households, firms and the government. They use production functions which describe the requirements on intermediates and factors to produce a unit of output in each sector and the intersectoral input-output linkages, which reflect the different sources of intermediates in goods and services. They also include a utility function, which describes the preferences of all consumers in the economy, as well as taxes and government transfers to other agents of the economy. In addition, they have equations describing national account identities, which have to be fulfilled together with the microeconomic optimisation behaviour of firms and households. Thus, the CGE model offers a comprehensive representation of the economy by incorporating real data of the economies into a rigorous theoretical framework.

In our model, we disaggregate the world economy in 21 sectors, five regions (UK, EU, USA, China and ROW) and four factors (skilled and unskilled labour, land, and capital). Capital and land are introduced as sector-specific, while labour is considered fully mobile across sectors within each region. This is a common assumption to calculate the short-run impact of economic phenomena, since it implies that capital and land can only be used in the sectors in which they are, according to the initial dataset, and cannot move across sectors. Therefore, changes in production are mostly driven by changes in labour demand. On the other hand, sectors are related to one another through domestic and imported intermediate inputs, cross-border trade in final goods and through competition in attracting labour. A detailed explanation of the model is available in the book by Hertel (1997) and has been updated in McDougall (2000). A more succinct explanation, including model equations, can be found in Zhou and Latorre (2014a, 2014b).

We run the model with a perfect competition setting, such as the one of Ottaviano et al. (2014) and Dhingra et al. (2017). According to Arkolakis, Costinot, and Rodríguez-Plana (2012) Armington, Krugman and Melitz models yield the same welfare gains (even when the number of sources of gains from trade varies across models). Welfare predictions in these trade models depend on only two sufficient statistics, the share of expenditure on domestic goods and the trade elasticity. ${ }^{6}$

\footnotetext{
${ }^{5}$ Kehoe et al. (2017) also compare the performance of NQTMs and CGEs. However, in contrast to our approach, they do not apply the same trade policy shock to both models, while here the analysis of Brexit is common to both methodologies.

${ }^{6}$ The share of expenditure on domestic goods is equal to one minus the import penetration ratio, while trade elasticity is the elasticity of imports with respect to variable trade costs.
} 
However, this welfare equivalence is sensitive to model assumptions and the type of trade policy instrument that is used in quantifying the economic effect of a shock. ${ }^{7}$

On the other hand, Balistreri and Tarr (2017) argue that including intermediate input trade (even in one-sector and one-factor models) alters the welfare equivalences of Arkolakis et al. (2012). They also find that adding multiple sectors magnifies the differences in the welfare predictions across models. In addition, Melitz and Redding $(2014,2015)$ consider that Arkolakis et al. (2012) underestimate the contribution of new theories of heterogeneous firms to the aggregate welfare implications of trade. Melitz and Redding $(2014,2015)$ indicate there is a potential channel (i.e. the endogenous changes in domestic productivity) which increases the welfare gains from trade. Therefore, they suggest that the share of expenditure on domestic goods and the trade elasticity are not enough to predict welfare gains from trade. According to their view Ottaviano et al. (2014), Dhingra et al. (2017) and all models that do not incorporate heterogenous firms, including ours, would provide lower bound estimates for the impact of Brexit on welfare.

Regarding trade, we simulate four scenarios, namely, zero tariffs, very soft, soft and hard Brexit. With zero tariffs, we assume that the UK and the EU continue to enjoy a free trade agreement; this means that Brexit does not lead to any change in tariffs barriers between both regions. In addition, in this scenario we also assume that the UK unilaterally removes all its tariffs on imports from the rest of its trade partners. In the very soft and soft Brexit, we consider that the UK and the EU remain tariffs at zero and apply NTBs with levels of $1 / 10$ and $1 / 4$ of the ones that Ecorys (2009) estimate exist between the EU and the USA. ${ }^{8}$

A "hard Brexit" would reflect the possibility of "no deal." This is a possible scenario, given that the UK's Parliament has rejected the WA on 16 January 2019, and is seeking to change it according to the vote of 29 January 2019, while the EU says it cannot be changed. The hard Brexit consists of two sub-scenarios. First, we increase import tariffs between the UK and the EU to the most favoured nation (MFN) level, and second, we assume an emergence of NTBS whose level is $1 / 2$ of the ones that Ecorys (2009) estimates exist between the EU and the US, following Ottaviano et al. (2014), Dhingra, Ottaviano, et al. (2016), and Dhingra et al. (2017). ${ }^{9}$ Modelling a disintegration process such as Brexit is a rather uncommon exercise given that in the last decades, we have been analysing the effects of globalisation ${ }^{10}$ (e.g. Latorre \& Yonezawa, 2018; Ortiz-Valverde \& Latorre, 2017). However, the logic is analogous and just the opposite; in one case, barriers to trade go down, and in the other, they increase.

The exact values for the barriers we run appear in Table 1, which shows the NTBs and MFN tariffs for every sector in the UK and in the EU. The percentages shown in Table 1 indicate the increase that the import price experiences when crossing the borders. Columns (2) and Columns (3) show the NTBs under a very soft and a soft scenario of Brexit, respectively. Columns (4) and Columns (5) show the NTBs and MFN tariffs with a hard Brexit scenario. The three dimensions bars suggest that NTBs would guide the bulk of Brexit's impact on trade. Additionally, we can see in Column (6), that the most protected sectors are agriculture, other primary and food; and to a lesser extent; textiles, motor

\footnotetext{
${ }^{7}$ See Akgul (2017), for an extensive analysis of the impact on welfare equivalence across models of relaxing the model assumptions.

${ }^{8}$ We follow the approach of Ottaviano et al. (2014) and Dhingra et al. (2017), see below.

${ }^{9}$ They consider that the UK will face only a share of the NTBs that the EU applies to the USA and simulate the emergence of barriers we have just described. We keep their simulations because by doing so we run the same barriers using a different approach. This may also be of interest from a methodological point of view.

${ }^{10}$ Some exceptions include the reduction in FDI inflows to China during the crisis (Latorre \& Hosoe, 2016) and disinvestments by foreign multinationals (Gómez-Plana \& Latorre, 2014).
} 
T A B L E 1 Non-tariff barriers and MFN tariff under Brexit

\begin{tabular}{|c|c|c|c|c|c|c|c|}
\hline \multirow{3}{*}{ Sectors } & \multirow{3}{*}{\begin{tabular}{|c|} 
Very Soft Brexit \\
NTBs to trade \\
In EU and UK \\
\end{tabular}} & \multirow{3}{*}{$\begin{array}{c}\text { Soft Brexit } \\
\text { NTBs to trade } \\
\text { In EU and UK }\end{array}$} & \multicolumn{5}{|c|}{ Hard Brexit } \\
\hline & & & \multirow{2}{*}{$\begin{array}{l}\text { NTBs to trade } \\
\text { In EU and UK }\end{array}$} & \multicolumn{2}{|c|}{ MFN tariff } & \multicolumn{2}{|c|}{ Total } \\
\hline & & & & In EU & \begin{tabular}{|l|} 
In UK \\
\end{tabular} & In EU & In UK \\
\hline Agriculture & $\begin{array}{r} \\
\end{array}$ & \begin{tabular}{l|r|} 
& 14.20 \\
\end{tabular} & 28.40 & \begin{tabular}{l|l|}
$\quad 10.20$ \\
\end{tabular} & $\quad 10.80$ & 38.60 & 39.20 \\
\hline Other primary & 5.68 & 14.20 & 28.40 & 0.00 & 0.10 & 28.40 & 28.50 \\
\hline Food & 5.68 & 14.20 & 28.40 & 19.80 & 22.00 & 48.20 & 50.40 \\
\hline Textiles & 1.92 & 4.80 & 9.60 & 10.00 & 9.50 & 19.60 & 19.10 \\
\hline Wood and paper & 1.12 & 2.80 & 5.70 & 0.50 & 1.00 & 6.20 & 6.70 \\
\hline Chemicals & 1.36 & 3.40 & 6.80 & 2.80 & 2.70 & 9.60 & 9.50 \\
\hline Metals & 1.20 & 3.00 & 6.00 & 1.90 & 2.00 & 7.90 & 8.00 \\
\hline Motor vehicles & 2.56 & 6.40 & 12.80 & 8.00 & 8.80 & 20.80 & 21.60 \\
\hline Other transport & 1.88 & 4.70 & 9.40 & 1.70 & 1.60 & 11.10 & 11.00 \\
\hline Electronics & 1.28 & 3.20 & 6.40 & 0.90 & 1.50 & 7.30 & 7.90 \\
\hline Other machinery & 0.00 & 0.00 & 0.00 & 1.70 & 1.80 & 1.70 & 1.80 \\
\hline Other manufactures & 1.12 & 2.80 & 5.70 & 2.60 & 2.20 & 8.30 & 7.90 \\
\hline Construction & 0.48 & 1.20 & 2.30 & & & 2.30 & 2.30 \\
\hline Water transport & 0.80 & 2.00 & 4.00 & & & 4.00 & 4.00 \\
\hline Air transport & 0.20 & 0.50 & 1.00 & & & 1.00 & 1.00 \\
\hline Communications & 1.16 & 2.90 & 5.90 & & & 5.90 & 5.90 \\
\hline \begin{tabular}{|l|} 
Finance \\
\end{tabular} & 1.12 & 2.80 & 5.70 & & & 5.70 & 5.70 \\
\hline Insurance & 1.08 & 2.70 & 5.40 & & & 5.40 & 5.40 \\
\hline Business services & 1.48 & 3.70 & 7.50 & & & 7.50 & 7.50 \\
\hline Personal services & 0.44 & 1.10 & 2.20 & & & 2.20 & 2.20 \\
\hline Other services & 0.44 & 1.10 & 2.20 & & & 2.20 & 2.20 \\
\hline
\end{tabular}

Source: Ecorys (2009) and Latorre et al. (2018).

vehicles, other transport, business services and chemicals. Therefore, the UK's exit from the EU would potentially harm these sectors more than others. These barriers should be viewed as the maximum barriers that could emerge between the UK and the EU. Some of these would appear soon after Brexit but others would take more time, as long as UK and EU regulations drift apart. However, if the UK's parliament eventually approves the WA and includes the "backstop" clause, North Ireland would be part of the EU customs union. In this case, the barriers would be much smaller than the ones shown in Table 1. The UK would have to follow EU regulations in goods markets. Therefore, NBTs in agriculture and manufactures would not emerge. Tariffs would also be zero since a customs union is also a free trade area. But hard NTBs would appear in services since they are not covered in the customs union.

Regarding trade itself, because services sectors are less trade-oriented than manufactures and agriculture, the impact of Brexit would considerably diminish. ${ }^{11}$ By contrast, financial services could be considerably harmed because they would be less competitive in the EU. However, it seems that for UK MPs the main trouble with the backstop is that the promises of sovereignty and of "taking back control" would not be fulfilled because the UK would have to follow EU regulation and would not be able to develop its own trade policy.

While economists have a lot of experience in analysing tariffs, modelling NTBs is more complicated. ${ }^{12}$ Both MFN tariffs and NTBs increase the costs of foreign trade. However, the latter does not provide revenues to governments, and the wedge between the world and domestic price may reflect economic rents for importers and exporters and also inefficiencies. Because NTBs will reduce competition from foreign firms, this will allow other firms to increase their prices and rents. In addition, if the NTBs create red tape or other unjustified bureaucratic processes, they cause a waste of resources. To simulate the rents and inefficiencies attributed to NTBs, we rely on the estimations of

\footnotetext{
${ }^{11}$ Note that Swiss banks, which do not have passporting rights, operate often through UK affiliates, even though Switzerland has a relatively close relationship with the EU based on many different sectoral agreements.

${ }^{12}$ NTBs are any measure different to tariffs that may be an obstruction to international trade. They comprise regulations, requirements and rules that impose how to manufacture, handle or advertise a good, the amount of a specific product that can be sold in a market, licenses or any specific sanitary certifications, among others. Because they are usually expressed as norms and rules, contrasting with the percentages costs associated with tariffs, it is difficult to quantify the costs they involve.
} 
Ecorys (2009) ${ }^{13}$ which quantified the ad valorem tariff equivalents ${ }^{14}$ (AVEs) of NTBs. They found that $60 \%$ of the NTBs would bring about efficiency losses, which are modelled as iceberg trade costs and $40 \%$ would generate rents. Additionally, they estimated that $2 / 3$ of the rents were earned by importers and $1 / 3$ by exporters.

Regarding migration, we extend previous analyses of Brexit (e.g. Ortiz-Valverde \& Latorre, 2018) by differentiating workers with respect to skill levels (skilled vs. unskilled).

Most of the uncertainty that has surrounded the immigration policy that the UK would apply diminished with the last 8 December 2017 "joint report" between the UK and the EU, ${ }^{15}$ whose conditions are included in the WA. Previous proposals showed more restrictive migration policies (for more details see Ortiz-Valverde \& Latorre, 2018).

The WA greatly facilitates that EU migrants in the UK and UK migrants in the EU remain in the same situation after Brexit. However, those EU citizens who arrive to the UK after the transition period (31 December 2020) will be subject to different migration conditions.

In the event of no deal, the EU citizens will be able to enter the UK to visit, work or study only for 3 months. In the case that they want to stay for more than 3 months, they should apply for a European Temporary Leave, which will be valid for 3 more years. EU citizens who want to stay for longer than 3 years will need to apply under the new immigration skills-based future immigration system, which will begin in 2021 (GOV.UK, 2019) and it is unknown. According to GOV.UK (2019), this policy is not applicable to EU migrants that already live or those who arrive at the UK before the exit day.

Under these conditions, it is clear that Brexit will not generate a massive exit of immigrants. That is why, regarding migration, we run an OECD scenario (Kierzenkowski et al., 2016) in which they estimate that the maximum possible reduction in migration flows would be of 116,000 persons per year. We follow their approach and interpret it as the maximum possible impact. In addition, this figure is in line with the 100,000 target of inflows of migrants that the UK government has sought for years, without success (Wadsworth, 2017b).

Kierzenkowski et al. (2016) simulate three scenarios, optimistic, central and pessimistic, in which the annual net migration into the UK would decline by 56,000, 84,000 and 116,000 persons per year. They also assume that $75 \%$ of the immigrants (independent of the scenario) would be in the labour force. This assumption is consistent with evidence of the participation of recent EU immigration inflows (Kierzenkowski et al., 2016). Applying this $75 \%$ to the maximum number of migrants $(116,000)$, we obtain the 87,000 reduction in the number of workers per year. Because controls on migration will in principle remain for some time, we accumulate this reduction in the inflow of workers throughout 5 years. This would be equivalent to a $1.45 \%$ of the stock of workers in the UK. First, we model two extreme simulations: one in which all migrants are skilled and another one in which all of them are unskilled. This means that we apply the increase of $1.45 \%$ to skilled and unskilled workers in turn.

\footnotetext{
${ }^{13}$ Ecorys (2009) relied on literature reviews, business surveys, gravity models and extensive consultations with regulators and businesses to calculate the ad valorem equivalents (AVEs) of the NTBs perceived by U.S. and EU firms across a wide variety of products. Because Ecorys (2009) did not provide values for agriculture, other manufacturing and other services, we take them from Latorre and Yonezawa (2018).

${ }^{14}$ The most straightforward way to model an NTB is to treat it as "tariff equivalent" (i.e., as an ad valorem equivalent, AVE). This is because NTBs increase the costs of importing goods and therefore they can be modelled similarly to tariffs with the nuances explained above. However, note that tariffs produce revenues for governments, while NTBs do not. Our model grasps this differential impact of both instruments.

${ }^{15}$ This "joint report" is a summary of the process made in the first phase of negotiations toward the "Withdrawal Agreement". Both parties have committed on some issues such as EU citizens' rights. However, the negotiations are not completed, and the implementations of such commitments will depend on the successful talks in the second phase (for an extended explanation see Peers, 2017).
} 
Then, we model a central scenario, labelled as "Mix" in the tables, in which we disaggregate the shock of $1.45 \%$ between both skills in proportion to their share in total EU immigrants that are employed in the UK. The latter shock involves $0.66 \%$ of skilled workers and $0.79 \%$ of unskilled workers (see Appendix 1 for a detailed explanation). ${ }^{16}$ Note that we do not know to which extent skilled and unskilled EU immigrants would be affected by migration restrictions.

We model the shock of $1.45 \%$ as an increase in the stock of workers and interpret the results as the foregone impact of the arrival of immigrants. This is because we follow the OECD estimations of a decline in the annual net inward migration into the UK. However, we have also modelled a decrease of $1.45 \%$ of labour and found that the results are the same. This means that our simulations can also be interpreted as the effects of EU migrants leaving the EU, which are also taking place according to Szary and McEnaney (2018).

In addition, we analyse the impact of migration taking into account two different set of parameter values for the elasticity of substitution among factors of production in all the sectors. ${ }^{17}$ First, we run the simulations using the current default values (standard elasticities) that GTAP Database (Aguiar, Narayanan, \& McDougall, 2016) provides. Then, in order to simulate the same scenarios, but with a smaller impact on wages, we re-run them assuming a higher elasticity of substitution among factors. To this aim, we follow the exercise done by Burfisher (2016, p. 317), in which she also analyses the effects of migration considering different categories of workers and different elasticities of substitution among factors using the GTAP model. The latter simulations are in line with the findings of the literature on UK migration.

According to Wadsworth (2015), Wadsworth, Dhingra, Ottaviano, and Van Reenen (2016), Wadsworth (2017a, 2017b) and Alfano, Dustmann, and Frattini (2016) there is no evidence of negative impacts of immigration on jobs, wages, housing or the crowding out of public services, and negative impacts on wages of less skilled groups are small. In addition, there is evidence suggesting that EU immigrants in the UK are initially "downgraded" and work in occupations which require lower skills than those they have (Alfano et al., 2016). This can be due to discrimination, lack of language skills and other factors. However, after some years they are usually "upgraded." This empirical trend provides support to the simulations that assume a higher elasticity of substitution between skilled and unskilled workers. The scenarios we have just described are summarised in Table 2.

\section{3 | DATA}

The database for micro and macroeconomic variables and the model's input-output framework come from the latest version of the GTAP 9 dataset for 2011 (Aguiar et al., 2016). Table 3 shows the share of each sector in total production, exports and imports. The first set of columns at the right of the table shows data for the UK, while the second set of columns corresponds to information for the EU.

In both regions, the weight of services in total production is well beyond $60 \%$, while their share is much smaller in trade. This reflects a worldwide trend, in which manufacturing goods account for $80 \%$ of total trade, despite their much lower share in production (e.g. Latorre et al., 2018).

\footnotetext{
${ }^{16}$ Note that the $1.45 \%$ is run as an increase in labour remuneration which is a common approach since CGEs do not model the exact number of workers but rather measures them as efficiency units (e.g., Latorre, 2016).

${ }^{17}$ This elasticity governs how easy it is to substitute factors of production within each sector. Because we assume that capital and land are specific, they remain fixed and cannot move across sectors. Thus, in the present modelling exercise this elasticity only determines the substitutability between skilled and unskilled labour.
} 
TA B L E 2 Trade and migration scenarios under Brexit

\begin{tabular}{|ll|}
\hline Trade scenarios & Conditions \\
\hline Zero tariff & Unilateral tariffs' elimination in UK (including zero tariffs on EU products). \\
\hline Very soft Brexit & Emergence of $1 / 10$ of the reference NTBs and zero tariffs between UK and EU \\
\hline Soft Brexit & Emergence of $1 / 4$ of the reference NTBs and zero tariffs between UK and EU \\
\hline Hard Brexit & Emergence of $1 / 2$ of the reference NTBs and MFN tariff increase (WTO rules) \\
& between UK and EU27. \\
& Change in number of \\
& workers $(\%$ and absolute \\
value) & $-1.45 \% 435,000($ i.e., \\
\hline OECD (2016) scenario & $87,000 \times 5)$ \\
& Skilled $(-0.66 \%)$, \\
\hline
\end{tabular}

Note: The reference NTBs are the barriers provided by Ecorys (2009).

Source: Author's estimations based on Eurostat (2017) database.

Other services, business services, construction and chemicals are the most important sectors in the UK's total production, with a share of $35.42 \%, 13.07 \%, 5.91 \%$ and $5.68 \%$, respectively. In the three former sectors, a large percentage of production goes to the domestic market (i.e. as intermediates, investment, private or public consumption). This implies that a drop in domestic demand would generate an important fall in their total production. By contrast, the increase in foreign trade costs arising from Brexit will diminish the UK's total production of manufactures that export and import an important share of their total output (e.g. motor vehicles, chemicals, textiles and other primary).

Table 4 shows the bilateral trade flows of the UK with the EU, the United States, China and the rest of the world. According to the data, the most important destinations of UK exports are EU and ROW, which account for $51.73 \%$ and $32.58 \%$ of its total exports, respectively. Regarding the origin of UK's imports, $49.41 \%$ come from the EU and $32.85 \%$ from ROW. Consequently, the increase in barriers to trade between the EU and UK will affect very important shares of the UK's trade. By contrast, the EU sells (buys) $54.23 \%$ (53.82\%) of its total exports (imports) within the EU and only $3.47 \%$ (5.75\%) of its trade flows are with the UK.

Migration policies would more intensively affect those sectors with the largest labour shares. Except for other primary, most sectors are labour-intensive. Hence, the latter could be more affected by a migration decline.

\section{4 | RESULTS}

\section{1 | Main macroeconomic aggregates}

\subsection{1 | International trade policy impacts on GDP, welfare and factors remuneration}

Table 5 shows the evolution of GDP, welfare (measured as Hicks equivalent variation), wages and capital remuneration under all scenarios. The results reflect an aggregation of all of the sectoral outcomes that will be analysed below. Being able to come up with results across sectors and regions shows why a CGE model is said to be consistent at the micro- and macroeconomic level (for more details see Latorre, 
TA B L E 3 Initial data: UK and EU shares in production, exports and imports by sector

\begin{tabular}{|c|c|c|c|c|c|c|}
\hline \multirow{2}{*}{ Sector } & \multicolumn{3}{|c|}{ United Kingdom } & \multicolumn{3}{|c|}{ European Union } \\
\hline & Output & Exports & Imports & Output & Exports & Imports \\
\hline Agriculture & 0.79 & 0.78 & 2.06 & 1.62 & 1.40 & 2.39 \\
\hline Other primary & 1.28 & 3.94 & 6.98 & 0.48 & 0.94 & 17.27 \\
\hline Food & 3.59 & 4.18 & 6.08 & 4.62 & 5.10 & 3.10 \\
\hline Textiles & 1.01 & 1.94 & 5.29 & 1.70 & 2.89 & 5.73 \\
\hline Wood and paper & 2.18 & 2.02 & 3.46 & 2.70 & 3.23 & 1.71 \\
\hline Chemicals & 5.68 & 18.54 & 14.86 & 7.49 & 18.17 & 15.34 \\
\hline Metals & 2.23 & 6.25 & 9.95 & 3.91 & 6.77 & 5.53 \\
\hline Motor vehicles & 1.86 & 7.55 & 8.56 & 3.23 & 9.79 & 3.35 \\
\hline Other transport & 1.15 & 4.00 & 2.94 & 1.01 & 3.45 & 2.90 \\
\hline Electronics & 0.80 & 3.27 & 5.10 & 1.24 & 3.55 & 6.91 \\
\hline Other machinery & 3.14 & 12.07 & 10.76 & 5.49 & 18.90 & 10.32 \\
\hline Other manufactures & 1.50 & 2.35 & 3.31 & 1.97 & 2.73 & 2.38 \\
\hline Construction & 5.91 & 0.40 & 0.28 & 6.55 & 1.18 & 0.71 \\
\hline Water transport & 0.90 & 0.52 & 0.56 & 0.77 & 1.14 & 0.81 \\
\hline Air transport & 0.97 & 3.01 & 2.75 & 0.75 & 2.78 & 2.03 \\
\hline Communications & 2.32 & 0.78 & 1.01 & 1.85 & 0.54 & 0.83 \\
\hline Finance & 3.62 & 5.92 & 2.19 & 2.97 & 0.90 & 2.45 \\
\hline Insurance & 1.92 & 1.43 & 0.34 & 1.01 & 0.96 & 0.41 \\
\hline Business services & 13.07 & 13.99 & 5.65 & 11.25 & 6.57 & 7.59 \\
\hline Personal services & 2.92 & 1.66 & 1.55 & 2.42 & 1.43 & 1.21 \\
\hline Other services & 35.42 & 5.42 & 6.32 & 27.97 & 7.59 & 7.03 \\
\hline Manufatures & 25.20 & 66.87 & 79.35 & 35.45 & 76.91 & 76.93 \\
\hline Services & 74.80 & 33.13 & 20.65 & 64.55 & 23.09 & 23.07 \\
\hline Total & 100.00 & 100.00 & 100.00 & 100.00 & 100.00 & 100.00 \\
\hline
\end{tabular}

Source: Authors' estimations based on GTAP 9 data base.

2012, 2013). We present the results for five regions. Interestingly, the impact of Brexit seems confined to the two regions directly involved in it, while for the rest the effect would be negligible.

Tariffs' elimination in the UK would lead to a tiny increase in its GDP by $0.04 \%$. However, the UK would face small reductions in welfare and factors' remuneration. Concerning the welfare loss, after the increase of imported goods coming from third countries the UK reduces its trade with the EU. Because the EU is a very efficient partner this is a trade diversion effect which reduces welfare in the UK. The EU's factors of production would also lose slightly after the UK's tariffs elimination.

We will see below that aggregate production would experience a tiny increase $(0.05 \%)$, with several sectors decreasing their production. ${ }^{18}$ In particular, the UK's sectors that contract output employs more than $50 \%$ of the total stock of labour and capital. This explains the downward pressure on wages and capital rents.

Under the very soft and soft Brexit, the UK would experience a decrease in GDP, welfare, wages and capital remuneration. The decline in GDP seems to be explained by the reduction of total production, due to the drop in output of industries such as motor vehicles, other primary, electronics,

\footnotetext{
${ }^{18}$ The results appear in Table 6 which will be analysed below.
} 
T A B LE 4 Initial data: UK bilateral exports and imports

\begin{tabular}{|c|c|c|c|c|c|c|c|c|c|c|}
\hline \multirow{2}{*}{ Sector } & \multicolumn{5}{|c|}{ Exports to } & \multicolumn{5}{|c|}{ Imports from } \\
\hline & EU27 & US & $\begin{array}{l}\text { China } \\
\end{array}$ & ROW & Total & EU27 & US & $\begin{array}{l}\text { China } \\
\end{array}$ & ROW & Total \\
\hline Agriculture & 75.94 & 3.59 & 5.40 & 15.06 & 100.00 & 49.28 & 4.03 & 1.79 & 44.89 & 100.00 \\
\hline Other primary & 72.89 & 4.57 & 0.09 & 22.45 & 100.00 & 11.90 & 1.52 & 0.07 & 86.52 & 100.00 \\
\hline Food & 61.78 & 9.10 & 0.96 & 28.17 & 100.00 & 75.18 & 3.00 & 1.57 & 20.25 & 100.00 \\
\hline Textiles & 66.15 & 4.98 & 2.15 & 26.72 & 100.00 & 33.27 & 1.65 & 25.61 & 39.48 & 100.00 \\
\hline Wood and paper & 53.99 & 9.48 & 7.11 & 29.42 & 100.00 & 63.40 & 7.43 & 14.04 & 15.13 & 100.00 \\
\hline Chemicals & 58.77 & 14.45 & 2.09 & 24.69 & 100.00 & 58.51 & 10.37 & 3.87 & 27.25 & 100.00 \\
\hline \begin{tabular}{|l|} 
Metals \\
\end{tabular} & 46.26 & 7.23 & 5.24 & 41.27 & 100.00 & 35.78 & 17.00 & 4.14 & 43.08 & 100.00 \\
\hline Motor vehicles & 53.25 & 9.70 & 7.92 & 29.14 & 100.00 & 84.59 & 1.61 & 1.12 & 12.68 & 100.00 \\
\hline Other transport & 36.57 & 16.32 & 1.82 & 45.30 & 100.00 & $\overline{38.16}$ & 32.21 & 2.55 & 27.08 & 100.00 \\
\hline \begin{tabular}{|l|} 
Electronics \\
\end{tabular} & 63.04 & 6.80 & 2.42 & 27.74 & 100.00 & 44.41 & 7.95 & 26.09 & 21.55 & 100.00 \\
\hline Other machinery & 40.06 & 14.98 & 4.73 & 40.23 & 100.00 & 56.32 & 13.27 & 9.93 & 20.49 & 100.00 \\
\hline Other manufactures & 42.03 & 15.63 & 1.09 & 41.25 & 100.00 & 38.80 & 17.68 & 21.33 & 22.19 & 100.00 \\
\hline \begin{tabular}{|l|} 
Construction \\
\end{tabular} & 42.51 & 2.59 & 0.69 & 54.22 & 100.00 & 39.14 & 2.73 & 10.48 & 47.65 & 100.00 \\
\hline Water transport & 46.62 & 1.36 & 0.23 & 51.79 & 100.00 & 60.63 & 2.79 & 0.88 & 35.71 & 100.00 \\
\hline Air transport & 41.82 & 17.03 & 0.49 & 70.66 & 100.00 & 55.74 & 9.87 & 0.27 & 34.11 & 100.00 \\
\hline Communications & 65.70 & 6.85 & 0.28 & 27.17 & 100.00 & 48.01 & 13.56 & 1.72 & 36.72 & 100.00 \\
\hline Finance & 42.62 & 24.54 & 1.01 & 31.84 & 100.00 & 32.22 & 33.52 & 0.25 & 34.00 & 100.00 \\
\hline Insurance & 22.26 & 43.99 & 1.72 & 32.03 & 100.00 & 53.29 & 20.46 & 1.38 & 24.87 & 100.00 \\
\hline Business services & 60.78 & 4.70 & 2.12 & 32.39 & 100.00 & 40.73 & 12.29 & 3.56 & 43.42 & 100.00 \\
\hline Personal services & 52.36 & 10.93 & 0.85 & 35.86 & 100.00 & 48.78 & 25.39 & 1.11 & 24.72 & 100.00 \\
\hline Other services & 740.61 & 21.55 & 2.07 & 35.77 & 100.00 & 46.44 & 17.95 & 1.90 & 33.70 & 100.00 \\
\hline \begin{tabular}{|l|} 
Manufacturing \\
\end{tabular} & 53.18 & 11.64 & 3.49 & 31.69 & 100.00 & 51.20 & 9.38 & 7.88 & 31.55 & 100.00 \\
\hline \begin{tabular}{|l|} 
Services \\
\end{tabular} & 49.60 & 14.96 & 1.55 & 33.90 & 100.00 & 44.75 & 17.02 & 1.98 & 36.24 & 100.00 \\
\hline Total & 51.73 & 12.98 & 2.70 & 32.58 & 100.00 & 49.41 & 11.50 & 6.24 & 32.85 & 100.00 \\
\hline
\end{tabular}

Source: Authors' estimations based on GTAP 9 data base.

TA B LE 5 Macroeconomic impact of Brexit in the UK
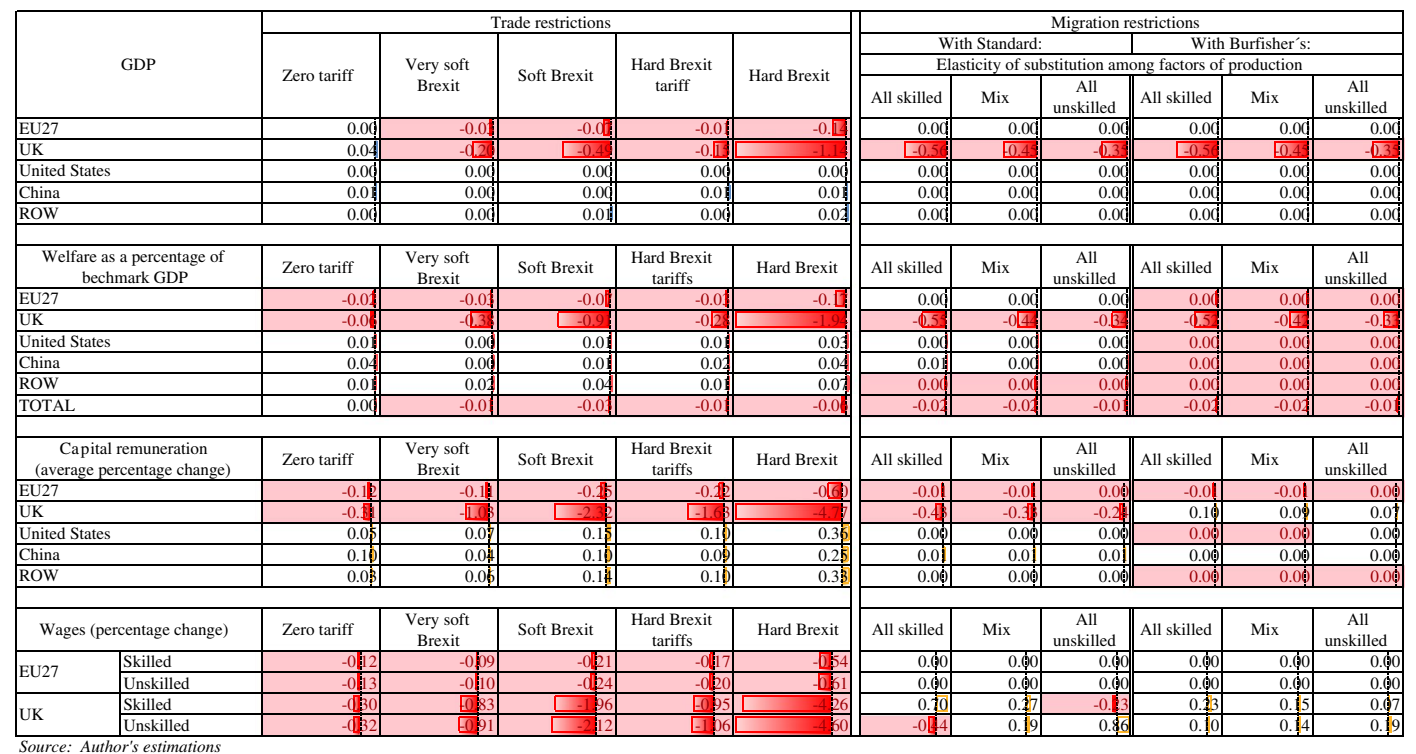

Note: The standard values for the elasticity of substitution between factors of production in each sector use the default GTAP values and the values of Burfisher (2016) are used in the other set of simulations.

construction and other services. Some of them reduce their exports and face a reduction in domestic demand. This negatively affects their outcomes. On the other hand, these industries employ 59.70\% of the UK's labour stock. As a consequence, there is a decrease in wages and private consumption. Increased trade barriers lead to a reduction in imports, allowing local firms to supply these goods and 
T A B L E 6 Effects of trade restrictions in total production, exports and imports in the United Kingdom by industry (percentage change)

\begin{tabular}{|c|c|c|c|c|c|c|c|c|c|c|c|c|c|c|c|c|}
\hline & \multicolumn{7}{|c|}{ Aggregate Production } & \multicolumn{5}{|c|}{ Aggregate Exports } & \multicolumn{4}{|c|}{ Aggregate Imports } \\
\hline & Zero tariff & \multicolumn{2}{|c|}{ Soft Brexit } & \multicolumn{2}{|c|}{\begin{tabular}{|c|} 
Hard Brexit \\
Tariffs
\end{tabular}} & \multicolumn{2}{|c|}{ Hard Brexit } & Zero tariff & Soft Brexit & \multicolumn{2}{|c|}{$\begin{array}{c}\text { Hard Brexit } \\
\text { Tariffs }\end{array}$} & Hard Brexit & Zero Tariff & \multirow{2}{*}{ 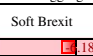 } & \multirow{2}{*}{$\begin{array}{c}\begin{array}{c}\text { Hard Brexit } \\
\text { Tariffs }\end{array} \\
\text { 目.39 }\end{array}$} & Hard Brexit \\
\hline UK & 0.05 & & & & & & & 1.47 & {$[2.95$} & & 3.89 & [ 7.31 & $1: 12$ & & & -13.49 \\
\hline \begin{tabular}{|l|} 
to or from $E U$ \\
\end{tabular} & & & & & & & & 1.38 & $\square .79$ & & 0.20 & $\begin{array}{l}.74 \\
\end{array}$ & $\sqrt{391}$ & & & \\
\hline to or from Third Regions & & & & & & & & 1.72 & 7.14 & & 2.32 & 14.59 & $5 ; 38$ & $2 ; 83$ & $3 ; 61$ & $8 ; 86$ \\
\hline EU27 & -0.01 & & $-0(122$ & & -0 -01 & & -0.0 望 & 年. & -1.174 & & .184 & 0.40 & $\begin{array}{cc}-0.07 \\
-0.07\end{array}$ & -1.42 & -4.31 & -196 \\
\hline \begin{tabular}{|l|} 
to or from $E U 27$ \\
\end{tabular} & & & & & & & & dit 105 & d.804 & & 749 & 1.96 & $0 ; 11$ & $0 ; 80$ & $0 ; 75$ & $1 ; 96$ \\
\hline to or from UK & & & & & & & & Bg10 & & & 858 & 3.20 & $1 ; 38$ & -1279 & जाव 20 & \begin{tabular}{|l|l|}
-23 & 74 \\
\end{tabular} \\
\hline to or from Third Regions & & & & & & & & d.531 & d 836 & & 749 & 2.14 & -047 & $-0 ; 04$ & $-0 \mid 28$ & 938 \\
\hline United States & 0.81 & & $0 . \overline{2} 2$ & & 0.02 & & 0.01 & 0.00 & 0.13 & & 0.11 & 0.00 & d.09 & d.19 & d.14 & d.09 \\
\hline \begin{tabular}{|l|} 
China \\
\end{tabular} & 0.00 & & 0.01 & & 0.11 & & 0.00 & 0.08 & 0.07 & & 0.05 & 0.08 & d.16 & 0.06 & d.09 & d.16 \\
\hline \multirow[t]{2}{*}{ Rest of the World } & 0.60 & & 0.02 & & 0.02 & & 0.00 & 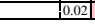 & +0.05 & & 0.01 & 0.02 & 0.04 & d.19 & 0.11 & 0.04 \\
\hline & \multicolumn{7}{|c|}{ Production in UK } & \multicolumn{5}{|c|}{ Exports in UK } & \multicolumn{4}{|c|}{ Imports in UK } \\
\hline Sectors & Zero Tariff & Soft Bre & & \begin{tabular}{|r} 
Hard $\mathrm{Br}$ \\
Tarif
\end{tabular} & & Hard B & Brexit & Zero Tariff & Soft Brexit & $\begin{array}{c}\text { Hard Brexit } \\
\text { Tariffs }\end{array}$ & & Hard Brexit & Zero Tariff & Soft Brexit & $\begin{array}{c}\text { Hard Brexit } \\
\text { Tariffs }\end{array}$ & Hard Brexit \\
\hline \begin{tabular}{|l|} 
Agriculture \\
\end{tabular} & -0.36 & & 0.04 & & -0.45 & & 0.96 & 374 & \begin{tabular}{|r|}
-3.01 \\
\end{tabular} & -23 & 62 & $\begin{array}{r}5.18 \\
\end{array}$ & 0,53 & -912 & E-687 & $-16,69$ \\
\hline \begin{tabular}{|l} 
Other primary \\
\end{tabular} & 0.01 & & -0.08 & & 0.02 & & -0.07 & $-(25$ & \begin{tabular}{|l|l|}
-23.02 \\
\end{tabular} & & 甚97 & $\begin{array}{r}-33.92 \\
\end{array}$ & $0+21$ & -11ilio5 & -1153 & -1651 \\
\hline Food & -0.84 & & -0.20 & & -0.36 & & 0.98 & 33 & -26 & 4.3 & 96 & \begin{tabular}{|r|}
$-5,41$ \\
\end{tabular} & 6 & $\begin{aligned} 192 \\
\end{aligned}$ & -2250 & $\begin{array}{lll} & -41 \\
\end{array}$ \\
\hline Textiles & -3.44 & & 0.14 & $\square$ & -3.56 & & -1.72 & 895 & [1. 39 & $\square-3$ & 08 & -33.22 & 8 & $-5 ; 53$ & 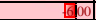 & -1352 \\
\hline Wood and paper & 0.16 & & 1.31 & & 0.77 & & 2.95 & 147 & -172 & & ing & $-\frac{6}{6} .64$ & $-0 \mid 13$ & 这18 & $-2 \sqrt{48}$ & -134 \\
\hline \begin{tabular}{|l|} 
Chemicals \\
\end{tabular} & 0.26 & & 0.38 & & 1.95 & & -1.74 & 19 & 1.29 & & 它.74 & 1128 & $0 \div 64$ & 543 & -681 & -1287 \\
\hline \begin{tabular}{|l|} 
Metals \\
\end{tabular} & 0.75 & & 0.45 & & 1.04 & & 0.04 & 230 & -19 & & 63 & .9.27 & 1:01 & -2166 & -294 & E6 76 \\
\hline Motor vehicles & 0.71 & L & -3.42 & $\square$ & -5.55 & 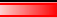 & -7.79 & 195 & 11.44 & {$[-18$} & 79 & \begin{tabular}{|l|l|}
-30 \\
\end{tabular} & 0.63 & -959 & 1030 & -2501 \\
\hline Other transport & 0.69 & & 0.53 & & 0.33 & & 1.60 & it 47 & -1.79 & & 127 & E. 66 & 1,43 & 7 & -280 & {$[-1424$} \\
\hline \begin{tabular}{|l} 
Electronics \\
\end{tabular} & 0.78 & & -0.85 & & 0.00 & & -1.76 & 240 & 1.49 & & 86 & 테. 88 & 0,55 & -508 & -2126 & -1099 \\
\hline Other machinery & 0.78 & & 2.70 & & -0.18 & & 4.44 & 421 & $5 \neq 1$ & & 16 & 7,54 & 092 & -286 & -6 & E 26 \\
\hline Other manufactures & 0.03 & & 0.32 & & -0.28 & & 0.19 & in:22 & -0.07 & & 67 & -1.92 & 1,12 & Siं95 & -641 & -1332 \\
\hline \begin{tabular}{|l|} 
Construction \\
\end{tabular} & 0.16 & $\square$ & -2.48 & & -1.26 & $\square$ & -5.42 & d87 & 675 & & 377 & 15,57 & $-0 \mid 30$ & 42 & $-\frac{1}{2} 22$ & -1530 \\
\hline Water transport & 10.40 & & 1.14 & & 0.59 & & 2.51 & dit & 1,02 & & d61 & 2127 & $0 ; 03$ & $1 / 43$ & -0.23 & $-2 \mid 87$ \\
\hline Air transport & 0.47 & & 7.45 & & 0.58 & & 2.88 & i 80 & $2 \sqrt{35}$ & & i93 & 474 & $-0 \mid 34$ & -173 & -032 & $-\frac{144}{4}$ \\
\hline Communications & 0.11 & & 0.47 & & 0.47 & & 1.11 & di 79 & -4.51 & & i97 & $-d .36$ & $-0 \mid 40$ & -62 & $-0 \mid 75$ & - 30 \\
\hline Finance & 0.26 & & 0.82 & & 0.78 & & 1.95 & dis8 & व.69 & & 163 & 203 & -0122 & -100 & -0158 & 1612 \\
\hline Insurance & 0.01 & & 0.39 & & 0.42 & & 0.99 & d85 & 328 & & 421 & 7.63 & $-0 \mid 53$ & 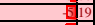 & -0 & E1037 37 \\
\hline Business services & 0.18 & & 0.14 & & 0.39 & & 0.44 & d68 & -4.80 & & 412 & -6.77 & $-0 \mid 35$ & -532 & -1109 & E1068 68 \\
\hline Personal services & 0.01 & & 0.34 & & 0.40 & & 0.87 & d99 & 399 & & 429 & 9.00 & $-0 \mid 59$ & $-\frac{18}{8} 86$ & $-0 \mid 95$ & -785 \\
\hline Other services & -0.12 & & -0.08 & & 0.21 & & -0.06 & 120 & 4.65 & & 237 & 10,42 & -0772 & - 19 & -1118 & $-8,56$ \\
\hline
\end{tabular}

compete with imports. However, the increasing competitiveness of local industries is due to the emergence of tariffs and non-tariff restrictions, and not to a real efficiency improvement.

Welfare drops by $-0.38 \%$ and $-0.9 \%$ under the very soft and soft Brexit, respectively. This is because, as we mentioned above, both NTBs and import tariffs reduce competition from other firms and allow inefficient firms to increase their prices. Furthermore, NTBs create some red tape. Thus, they cause a waste of resources.

The negative effects of Brexit would be larger if the UK and the EU increased NTBs, by more than in the soft Brexit, and also include MFN tariffs. This is what happens in the hard Brexit, in which the UK would experience a GDP decrease of $-1.14 \%$. Interestingly, our results are close to the ones of Ciuriak et al. (2017). Their Brexit scenario, which is the one that is more similar to our hard Brexit, yields a $-1.35 \%$ reduction in GDP in the UK, and a $-0.13 \%$ for the EU. On the other hand, their Brefta scenario, the closest to our soft version, yields a $-0.65 \%$ reduction for the UK and a $-0.07 \%$ for the EU. The EU would face rather small negative effects in GDP, welfare, wages and capital remuneration, too. In fact, the impact is considerably lower than in the UK. As happened in the case of the UK, however, factor remunerations tend to be more affected than GDP and welfare. Note that many studies on Brexit do not offer the impact on EU aggregates. In addition, as we can see, the magnitude of the impact of trade costs on skilled and unskilled labour remuneration is similar. This suggests that at least at the income channels, the Brexit trade shocks are likely to be evenly distributed across income groups.

Our results are also in line with the others in the literature. This becomes clear when we decompose total from other papers into the elements that are comparable with the ones of our model. For example, Jafari and Britz (2018) obtain in a Melitz framework an impact on GDP from NTBs and tariffs of -1.08 and $-0.29 \%$, respectively. This would be only slightly larger than our joint $-1.14 \%$ impact on GDP (composed of $-0.15 \%$ reduction due to tariffs and the rest being explained by NTBs $-0.99 \%$ ).

Finally, we derive even larger impacts than the ones of the influential study by Dhingra et al. (2017). For a hard Brexit, our reduction is of $-1.94 \%$, while they obtain $-2.66 \%$. However, in their more detailed welfare decomposition, shown in Table 4 (Dhingra et al., 2017), ${ }^{19}$ we see that the most

\footnotetext{
${ }^{19}$ To the best of our knowledge, this table was not in the working paper version of the paper (Dhingra, Huang, et al., 2016).
} 
important contribution to their overall total welfare impact $(-2.66 \%)$ is the absence of future EU integration $(-1.61 \%)$. It surpasses the joint contribution of NTBs and tariffs $(-1.31 \%$ and $-0.13 \%$, respectively). ${ }^{20}$ Our welfare reduction for the UK after the soft Brexit $(-0.91 \%)$ is also larger than the impact of the increase in NTBs they obtain $(-0.53 \%)$. We can hypothesise, in line with the findings of Balistreri and Tarr (2017) and Costinot and Rodríguez-Clare (2014), that the more structure you add to the model, the larger the impact obtained compared to a more stylised model, such as NQTM.

\subsection{2 | Impacts of the UK's migration policy on GDP, welfare and factors remuneration}

Unlike other previous analyses (e.g. Ortiz-Valverde \& Latorre, 2018), in this paper, we describe the impact of a restriction on migration considering skilled and unskilled labour for 5 years. Therefore, Table 5 depicts potential results under the migration restrictions scenarios, that is all skilled, all unskilled, and a reduction proportional to the share of EU skilled and unskilled workers labelled as "mix" (see columns (6) to columns (11)). Recall that in this scenario we follow the OECD estimations of a decline in the annual net inward migration into the UK by 116,000 persons per year over 2019-23 and that $75 \%$ of this would be reflected in the labour force. As mentioned above, we accumulate this reduction in the inflow of workers throughout 5 years. We model an equivalent increase of $1.45 \%$ of the stock of workers. As noted above, the results can be interpreted as foregone impacts due to impediments to immigrants' arrival or as the effects of EU migrants leaving the UK.

Due to the immigration restriction, the UK would face a potential GDP loss between $-0.35 \%$ and $-0.56 \%$ (or US $\$ 8,485.43$ and US $\$ 13,570.76$ million, respectively) depending on whether the shock in migration is only applied to all unskilled or all skilled workers. In our central scenario, in which we assume a simultaneous change in the flow of skilled and unskilled workers, the potential GDP loss would be of $-0.45 \%$ (or US $\$ 11,043.75$ million).

In contrast to the rest of the results of this paper, the GDP per capita has not been obtained directly from our model. The GDP per capita is a back of the envelope calculation, taking into account the evolution of GDP and a rough calculation of the decrease in population associated with the reduction in the number of workers. ${ }^{21}$ Immigration restrictions would imply a rise in GDP per capita of $0.33 \%$, $0.44 \%$ or $0.54 \%$ if all skilled, both type of workers or only all unskilled workers were affected, respectively.

In the case of standard elasticities, restrictions on all skilled (all unskilled) labour, the wages of skilled (unskilled) workers increase by $0.70 \%$ (0.86\%). Restrictions on workers of a particular labour category lead to a decline in the supply of that labour category and consequently to an increase of its remuneration. However, the other labour category and capital become relatively more abundant and their remunerations fall. These results suggest some trends for factors' inequalities arising from migration that would contradict the UK evidence on migration (Wadsworth, 2015; Wadsworth et al., 2016).

On the other hand, the effect of a joint reduction in the number of skilled and unskilled workers (mix scenario) would lead to a small and relatively balanced impact on their remunerations. Restrictions in both types of labour supply are more similar than before so that both types of workers become less

\footnotetext{
${ }^{20}$ The authors explain that their decomposition does not add up to the total of $-2.66 \%$ because they are performing "three different counterfactual exercise (per scenario) instead of one" (Dhingra et al., 2017).

${ }^{21}$ The values for GDP per capita are obtained subtracting from the rate of variation of GDP (in Table 5) the rate of variation of population in Table 1 (0.89 per cent). As is well known, the properties of logarithms (i.e., $\operatorname{Ln}(A / B)=\operatorname{Ln}(A)-\operatorname{Ln}(B))$ can be applied to the rates of growth. We take the exact decreases in the number of all immigrants (not only workers) as reductions in population, i.e., the annual amount is 116.000 as estimated by the OECD.
} 
abundant and slightly better remunerated. However, firms still suffer from labour scarcity and experience an average lower capital remuneration.

When we analyse the impact of migration restrictions, considering a higher elasticity of substitution among factors for production, the impact on factor remunerations is less intense than with default elasticities. When workers become more easily substitutable within each sector the impact on wages is much smaller (this is in line with the literature on UK migration) turning slightly positive across skill categories. More flexibility helps business on average and their remuneration also turns positive, although close to zero. The overall negative impact on welfare is slightly less negative now. Recall that capital is specific so that it cannot move across sectors. This dampens considerably the impact of any changes in elasticities dealing with factors' substitutability, and that is why the outcomes in GDP and welfare are so similar.

The higher the elasticity of substitution among factors, the smaller the impact on wages is. Therefore, we can assume that a decrease or an increase of EU workers in the UK would not increase inequality. This is in line with the findings of Wadsworth (2015), who suggests that the pressure of immigrants in the UK is more likely to reduce inequality, due to the fact that they are more skilled than immigrants in other countries.

Our current results for migration indicate that small restrictions to the flows of migrants or reductions in their stock would be slightly positive for GDPpc. However, because they are not directly derived from our model, except for GDP itself, they should be taken with a pinch of salt. They suggest that in line with the literature, migration does not necessarily reduce wages. Interestingly, though, because not all migrants are workers, the arrival of the ones that do not work puts downward pressure on GDPpc. ${ }^{22}$

\section{2 | Production, exports and imports}

\subsection{1 | International trade policy impacts on production and trade flows}

Table 6 presents the evolution in production, exports and imports. On the top of the table, there are three blocks of columns, which depict the aggregate impact on those variables for the five regions of the model. ${ }^{23}$ Below appear the details by sector in the UK. Each block of columns shows the results under four scenarios: zero tariffs, soft, hard Brexit tariffs and hard Brexit (which includes both tariffs and NTBs). We concentrate in these scenarios because they grasp the essence of the sector adjustment and keep the tables manageable.

The elimination of tariffs in the UK would generate a tiny increase in total production $(0.05 \%)$, with small rises in overall exports and imports (by $1.47 \%$ and $1.12 \%$, respectively). The EU would remain nearly unaffected across these aggregates.

Agriculture, food, textiles and motor vehicles are the sectors with the largest tariffs (Table 2). Therefore, removing them in the UK would imply that domestic firms in these sectors could face more competition than the rest of sectors and hence would reduce their production. Notice that zero tariffs lead to a lower cost of imported goods and hence consumers and producers in the UK would have access to cheaper final and intermediate imported goods. Zero tariffs would push up UK's imports in agriculture $(0.53 \%)$, food $(6.06 \%)$, textiles $(8.49 \%)$ and motor vehicles $(0.63 \%)$. As we can see,

\footnotetext{
${ }^{22}$ Note that in the trade scenarios percentage changes in GDP and in GDPpc coincide because there is no change in population.

${ }^{23} \mathrm{We}$ also present the results for bilateral trade for the UK and the EU.
} 
production in three former sectors would fall while motor vehicles would be positively affected. This is because motor vehicles exports more than $50 \%$ of its total production, while the other sectors sell a larger share of their total production in the domestic market.

Looking at the detail on bilateral data we see that removing tariffs in the UK would lead to an increase in its imports coming from third countries (5.38\%). However, imports coming from the EU would fall $(-3.91 \%)$. This is due to the fact that imported goods coming from the EU do not experience any reduction in terms of tariffs. In other words, with zero UK tariffs, EU goods would face the same conditions they currently enjoy. Thus, the UK would divert its imports from the EU by substituting them with imports from third regions. This trade diversion would bring about a substitution from more-efficient trade partners to other less-efficient. Turning to the bilateral trade data of the EU, we observe that the EU's imports coming from third regions would fall $(-0.47 \%)$. The UK's market would be more attractive than the European, once the UK's tariffs barriers have been eliminated.

The emergence of NTBs would imply a reduction in the UK's aggregate production of $-0.27 \%$. This fall would be associated with the decline of total production in other primary, food, motor vehicles, electronics construction and other services. As we will note below, the impact in the first four sectors would be larger under a hard Brexit scenario, in which NTBs double their values regarding soft Brexit scenario. The emergence of NTBs reduces imports in all sectors $(-6.18 \%)$, especially those coming from the EU $(-13.53 \%)$. In addition, the aggregate exports would face a reduction of $-2.95 \%$, due to the decline in most of the manufactures sectors. The exports going to the EU fall by $-12.79 \%$.

On the other hand, the simultaneous increase of NTBs and tariffs (Hard Brexit) leads to a fall in the UK's total production by $-0.71 \%$, in which $-0.30 \%$ of it is explained by the emergence of tariffs (hard Brexit tariffs). The decline of $-0.71 \%$ is due to the reduction of production in construction, other services, electronics, motor vehicles, textiles, chemicals and other primary. The drop in the production of the latter five sectors would be related to the share of their total production that is sold abroad (mainly in the EU market). The existence of NTBs leads to an export decrease to the EU and hence a decrease in total production. By contrast, the fall in other services would be related to the behaviour of domestic demand. This is because on average $31 \%$ of their total production is used as intermediates in the industries which would experience a production decline. Construction would be affected because of a fall in aggregate investment after Brexit.

Although the UK increases exports to third regions by $14.59 \%$ (2.32\% of this rise is due to the emergence of tariffs between the UK and the EU), the increase of $14.59 \%$ cannot compensate for the fall in exports to the EU (-28.74\%). In other words, the increase in the UK's exports to other regions would be limited by the existence of tariffs and NTBs in those markets and the importance of the European market for the UK's exports. In general, most sectors which sell a substantial share of their total exports to the EU (e.g. agriculture, other primary, food, textiles, motor vehicles, etc.) would face larger trade barriers costs, losing their previous preferential conditions.

Regarding the EU, it faces slight drops in its total production, exports and imports of $-0.04 \%$, $-0.40 \%$ and $-0.96 \%$, respectively. Even though the EU faces the same increase of NTBs as the UK, the effect of these trade barriers would be smaller because they affect a smaller share of total EU's exports and imports, than the other way around (Table 4). In addition, the EU could and would increase its intra-EU trade to compensate its export losses with the UK (under the same preferential trade conditions). Intra-EU trade would experience a rise of $1.96 \%$ (in which $0.75 \%$ of it would be explained by the emergence of tariffs) that is equivalent to US\$63,239.39 million in absolute terms. By contrast, the total bilateral exports to the rest of trade partners (the USA, China and ROW) would rise by $2.14 \%$ (i.e. US $\$ 49,464.52$ million). However, that increase is not enough to compensate for the fall in trade with the UK by $-33.2 \%$ (i.e. US $\$ 137,229.93$ million) and overall EU trade would still decline, although 
T A B L E 7 Effects of migration restrictions after Brexit in total production, exports and imports in the UK by industry (percentage change)

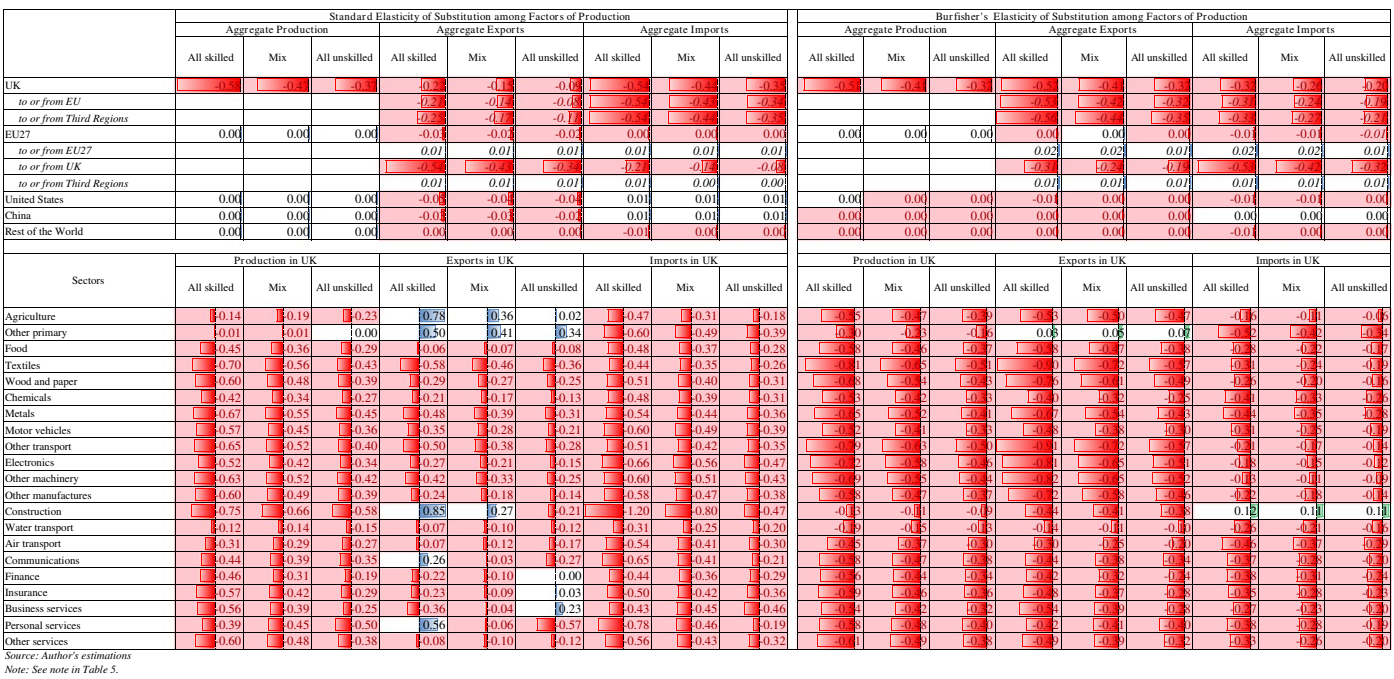

very slightly (by $-0.40 \%$, which is equivalent to US $\$ 24,596.02$ million). As we can see, the reduction of $-12.85 \%$ in the EU trade with the UK (Hard Brexit tariffs) would be explained by the increase in tariffs. This means that tariffs play an important role in the flow of goods between both the UK and the EU, costs of trade that could be avoided as a member of the EU.

In terms of imports, both the UK and the EU face a decline in their aggregate imports. In the case of the UK, hard Brexit leads to a reduction of imports coming from the EU of $-33.20 \%$, while the bilateral imports from the rest of its trading partners increase by $8.86 \%$. By contrast, the EU would experience a tiny decrease $(-0.38 \%)$ in its imports coming from third regions. The adjustment suggests that the EU would replace its imports coming from the UK and from third regions with intra-EU trade, due to the existence of EU trade barriers with UK, USA, China and ROW.

To sum up, if the UK unilaterally removes all of its tariffs and continues to enjoy the current zero tariffs with the EU, UK production and trade would remain nearly unaffected. These results are in line with the ones derived by Dhingra, Ottaviano, et al. (2016) and are different than the very positive ones of Minford et al. (2015). By contrast, if a hard Brexit comes into force, the aggregate exports and imports in both regions would experience a drop, contracting total production. It is important to note that the emergence of tariff plays an important role in the cost trade increases. Motor vehicles would be one of the most affected sectors in the UK, due to the emergence of trade costs, while construction would be affected by the adjustment of investment. Moreover, as noted, the impact of Brexit would be much larger in the UK than in the EU.

\subsubsection{Impacts of UK' migration policy on production and trade flows}

Table 7 provides the results of immigration restrictions on production and trade flows. It shows both the impact of migration policy with the default GTAP parameter values and the larger ones of Burfisher (2016) for the elasticity of substitution between factors of production. 
Most sectors in the UK employ skilled workers more intensively than unskilled ones. ${ }^{24}$ In addition, most industries in the UK are labour-intensive (with the exception of other primary). According to the Rybczynski theorem (1995), an increase in the endowment of one factor leads to an increase in the production of the good that uses that factor intensively, while the goods that do not use it intensively would face a decrease in their production. This implies that a decline in the number of workers would lead to a large fall across most sectors except for other primary goods.

We again run the impact of migration as a forgone impact or as immigrants leaving the UK. We begin our analysis with the results using standard GTAP elasticities (on the left of Table 7). Restrictions on the number of workers would imply a potential loss in aggregate production, exports and imports in the UK indistinctly of labour category. Unlike the impact on other primary (in which production would remain nearly unaffected), most of the sectors in the UK would face a loss in their total production. In addition, the effects of an immigration restriction would be most harmful when workers who go back to the EU are skilled.

The UK's production would face a loss of $-0.58 \%$ if the restrictions are applied to skilled workers versus a $-0.37 \%$ reduction if they are applied to unskilled ones, and of $-0.47 \%$ in the mix scenario, with larger values for the elasticity of substitution among factors of production (right of Table 7), that is using Burfisher's elasticities. The fall in the UK's aggregate production is slightly lower than in our standard estimates. More flexibility dampens the contraction of production. In addition, welfare which shows both the evolution of national income and private consumption is contracting a bit less now. Therefore, there is a somewhat larger (a smaller fall in) demand compared to the results with default elasticities. Thus, imports fall by less now for two reasons. First, because demand is relatively larger, imports that satisfy final consumption are also a bit larger than with the default elasticity. Second, since most of the imports are intermediates and production contracts less now, these imports also fall slightly less now than with the standard elasticity. By contrast, exports fall by more than in the standard case because factor prices are slightly larger now. When they were lower, they helped to overcome the emergence of tariffs and NTBs dampening slightly the fall in exports, due to lower factor costs.

Given the abundant evidence suggesting that we should not expect strong impacts on wages due to immigration, the most likely outcomes seem to be the ones with Burfisher's elasticities. These outcomes suggest very slightly lower losses for migration, compared to the ones with standard elasticities.

\section{5 | CONCLUDING REMARKS}

In this paper, we have estimated the quantitative impact of Brexit by means of a CGE model. In particular, we have investigated how the emergence of MFN tariffs, NTBs, a unilateral removal of the UK's tariffs, as well as restrictions to migration affect a broad set of micro and macroeconomic variables in the UK, the EU, the US, China and the rest of the world. We obtain results that are in line with the previous literature (e.g. Ciuriak et al., 2017; Jafari \& Britz, 2018) but considerably extend the outcomes that are usually analysed. One exception is noteworthy, however. We derive a considerably larger impact on welfare than the one derived in the influential paper of Dhingra et al. (2017). Although both models have an important array of features in common, our CGE methodology yields deeper impacts than their new quantitative trade model approach.

Our joint estimate of MFN tariffs and NTBs suggests that, if a hard or "no deal" Brexit comes into force, the UK would face a decrease in GDP $(-1.14 \%)$, welfare $(-1.94 \%)$ and capital rents $(-4.77 \%)$.

\footnotetext{
${ }^{24}$ Recall that our measures within the CGE model are based on labour remuneration which are calculated multiplying the number of workers by their wages. We obtain that most sectors are skilled intensive due to the high wages.
} 
In the case of wages, results would depend on whether Brexit affects more skilled or unskilled workers. In any case, the fall in wages would be between $-4.26 \%$ and $-4.60 \%$, with losses being larger when affected workers are skilled.

If the UK eliminates all tariffs with respect to all its trading partners, it will not be able to compensate for the above-mentioned losses. Running this scenario in isolation, its GDP remains nearly unaffected. This result contrasts with the one of Minford et al. (2015) who derived a positive impact for Brexit based on such a policy.

The immigration issue has played a very important role in the discussions previous to the referendum. The Withdrawal Agreement (WA) greatly facilitates that EU (UK) migrants may remain in the UK (EU). Even in a "no deal" Brexit, massive migration can be ruled out since the bulk of EU migrants that have arrived during the recent crisis would be able to stay. However, inflows of future migrants may be controlled after the transition period established in the WA and also after December of 2020 in a no-deal case. We model these potential annual restrictions of 116.00 EU migrants accumulated through 5 years. We find that migration is compatible with wage increases but puts downward pressure on GDPpc. However, immigration restrictions would not be able to compensate for the trade losses of a hard Brexit.

At the sectoral level, the number of industries that would be negatively affected would depend on the level of trade barriers that would emerge after Brexit. With zero tariffs, sectors like agriculture, food and textiles would face production falls. Tariffs' elimination increases the entry of more imported goods from regions, which are competitive in those sectors, thus increasing competition in the domestic market.

On the other hand, the emergence of barriers to trade (MFN tariffs and NTBs) would mainly affect the exports of the manufacturing industry. As a consequence, production in several industries fall (e.g. textiles, other primary, chemicals, motor vehicles and electronics). Motor vehicles would be the most affected sector, with a drop of $-7.7 \%$ in its output.

Even though estimates of migration and trade barriers allow us to have a clearer vision of the potential effects of Brexit, future extensions including foreign direct investment and multinationals would enrich the present analysis. We believe, however, that other elements considered in other studies like uncertainty (HM Government, 2016; Kierzenkowski et al., 2016; PwC, 2016) have so far failed to materialise to the degree that the (substantial) negative impact derived from them implied. The losses they suggested may have been overstated.

\section{ORCID}

Gabriela Ortiz Valverde (iD https://orcid.org/0000-0001-8436-4394

Maria C. Latorre (iD https://orcid.org/0000-0001-8741-1897

\section{REFERENCES}

Aguiar, A., Narayanan, B., \& McDougall, R. (2016). An overview of the GTAP 9 data base. Journal of Global Economic Analysis, 1(1), 181-208. https://doi.org/10.21642/JGEA.010103AF

Aichele, R., Felbermayr, G., Petersen, T., \& Schoof, U. (2015). Brexit - potential economic consequences if the UK exits the EU. Policy Brief \#2015/05. Future Social Market Economy, Bertelsmann Stiftung. Retrieved from: https://www.bertelsmann-stiftung.de/en/publications/publication/did/policy-brief-201505-brexit-potentialeconomic-consequences-if-the-uk-exits-the-eu/

Akgul, Z. (2017). One Model to rule them all? The importance of firm heterogeneity in CGE modeling of the gains from trade (Working paper series 2017-3-B). Centre for Global Trade Analysis, Purdue University and U.S. International Trade Commission website: https://www.usitc.gov/publications/332/zeynepakgul_litreview_itc_170327.pdf 
Alfano, M., Dustmann, C., \& Frattini, T. (2016). Immigration and the UK: Reflections after Brexit (Discussion Paper Series CPD 23/16). Retrieved from Centre for Research \& Analysis of Migration, University College London website: https://www.cream-migration.org/publ_uploads/CDP_23_16.pdf

Arkolakis, C., Costinot, A., \& Rodríguez-Plana, A. (2012). New trade models, same old gains? American Economic Review, 102(1), 94-130. https://doi.org/10.1257/aer.102.1.94

Balistreri, E. J., \& Tarr, D. (2017). Comparison of Welfare Results from Trade Liberalization in the Armington, Krugman and Melitz Models: Impacts with features of real economies. Presented at the 19th Annual Conference on Global Economic Analysis, Washington DC, USA, June 2016.

Booth, S., Howarth, C. H., Persson, M., Ruparel, R., \& Swidlicki, P. (2015). What if? The consequences, challenges and opportunities facing Britain outside EU (Report 03/2015). London, UK: Open Europe. Retrieved from https://opene urope.org.uk/intelligence/britain-and-the-eu/what-if-there-were-a-brexit/

Burfisher, M. (2016). Introduction to computable general equilibrium models (2nd ed.). New York, NY: Cambridge University Press.

Busch, B., \& Matthes, J. (2016). Brexit - The economic impact a meta-analysis (IW Report 10/2016). Cologne, Germany: Cologne Institute for Economic Research.

Caliendo, L., \& Parro, F. (2015). Estimates of the trade and welfare effects of NAFTA. Review of Economic Studies, 82(1), 1-44. https://doi.org/10.1093/restud/rdu035

Centre for Economic Performance. (2016). BREXIT 2016: Policy analysis from the Centre for Economic Performance. London School of Economics and Political Science, June. Retrieved from https://cep.lse.ac.uk/pubs/download/ brexit08_book.pdf

Ciuriak, D., Dadkhah, A., \& Xiao, J. (2017). Brexit trade impacts: Alternative scenarios. Retrieved fromhttps://papers. ssrn.com/sol3/papers.cfm?abstract_xml:id=2981314

Costinot, A., \& Rodríguez-Clare, A. (2014).Trade theory with numbers: quantifying the consequences of globalization. In E. Helpman, G. Gopinath, \& K. Rogoff (Eds.), Handbook of International Economics (Vol. 4, pp. 197-262). Amsterdam, The Netherlands: Elsevier.

Dhingra, S., Huang, H., Ottaviano, G., Pessoa, J. P., Sampson, T., \& Van Reenen, J. (2016). The costs and benefits of leaving the EU: Trade effects (CEP Discussion Papers 1478). London, UK: London School of Economics and Political Science. Retrieved from Centre for Economic Performance website: https://cep.lse.ac.uk/pubs/download/brexit08_book.pdf

Dhingra, S., Huang, H., Ottaviano, G., Pessoa, J. P., Sampson, T., \& Van Reenen, J. (2017). The costs and benefits of leaving the EU: Trade effects. Economic Policy, 32(92), 651-705. https://doi.org/10.1093/epolic/eix015

Dhingra, S., Ottaviano, G. I., Sampson, T., \& Van Reenen, J. (2016).The consequences of Brexit for UK trade and living standards. LSE Research Online Documents on Economics 66144, London School of Economics and Political Science, LSE Library. Retrieved from https://ideas.repec.org/p/ehl//serod/66144.html

Di Giovanni, J., Levchenko, A., \& Ortega, F. (2015). A global view of cross-border migration. Journal of the European Economic Association, 13(1), 168-202. https://doi.org/10.1111/jeea.12110

Dustman, C., \& Frattini, T. (2014). The fiscal effects of immigration to the UK. The Economic Journal, 124(580), F593-F643. https://doi.org/10.1111/ecoj.12181

Ecorys. (2009). Non-tariff measures in EU-US trade and investment - An economic analysis. Final report OJ 2007/S 180-219493, European Commission, Diretorate-General Trade.

Eurostat. (2017). Population on 1 January by age group, sex and citizenship. Retrieved from http://appsso.eurostat. ec.europa.eu/nui/show.do?dataset=migr_pop1ctz\&xml:lang=en

Eurostat. (2019a). Population by sex, age, citizenship and labour status. Retrieved from http://appsso.eurostat.ec.europa.eu/nui/show.do?dataset=lfsa_pganws\&xml:lang=en

Eurostat. (2019b). Population by educational attainment level, sex, age and citizenship. Retrieved from http://appsso. eurostat.ec.europa.eu/nui/show.do?dataset=edat_lfs_9911\&xml:lang=en

Eurostat. (2019c). Employment rates by sex, age, educational attainment level and citizenship. Retrieved from http:// appsso.eurostat.ec.europa.eu/nui/show.do?dataset=lfsa_ergaedn\&xml:lang=en

Fernández-Pacheco Theurer, C., López, J. L., \& Latorre, M. C. (2018). Multinationals' effects: A nearly unexplored aspect of Brexit. Journal of International Trade Law and Policy, 17(1/2), 2-18. https://doi.org/10.1108/ JITLP-12-2017-0053

Gancía, G. (2017). Discussion on the costs and benefits of leaving the EU: Trade effects. Economic Policy, 32, 691-695.

Gómez-Plana, A. G., \& Latorre, M. C. (2014). When multinationals leave: A CGE analysis of divestments. EconomicsThe Open Access Open-Assessment E-Journal, 8, 1-41. https://doi.org/10.5018/economics-ejournal.ja.2014-6 
GOV.UK. (2019). Government outlines no deal arrangements for EU citizens. Retrieved from https://www.gov.uk/gover nment/news/government-outlines-no-deal-arrangements-for-eu-citizens

Harrison, G. W., Jones, R., Kimbell, L. J., \& Wigle, R. (1993). How robust is applied general equilibrium analysis? Journal of Policy Modeling, 15(1), 99-115. https://doi.org/10.1016/0161-8938(93)90024-K

Hertel, T (1997) . Global trade analysis: Modelling and applications. Cambridge, UK: Cambridge University Press. Retrieved from: https://www.gtap.agecon.purdue.edu/resources/download/7685.pdf

Hertel, T., McDougall, R., Narayanan, B., \& Aguiar, A. (1998). Chapter 14: Behavioral parameters. In GTAP data base documentation. Retrieved from https://www.gtap.agecon.purdue.edu/databases/v9/v9_doco.asp

HM Government. (2016). HM Treasury analysis: The long-term economic impact of EU membership and the alternatives. Discussion paper. Retrieved from https://www.gov.uk/government/publications/hm-treasury-analysis-thelong-term-economic-impact-of-eu-membership-and-the-alternatives

ILO (2012). International Standard Classification of Occupations: Structure. ISCO-08 Volume I. International Labour Office, Geneva. Retrieved from https://www.ilo.org/public/english/bureau/stat/isco/isco08/index.htm

Jafari, Y., \& Britz, W. (2018). Brexit: An economy-wide impact assessment on trade, immigration, and foreign direct investment. Empirica Online , 1-36. https://doi.org/10.1007/s10663-018-9418-6

Kehoe, T., Pujolàs, P., \& Rossbach, J. (2017). Quantitative TRADE Models: Developments and challenges. Staff Report 537, Research Division Federal Reserve Bank of Minneapolis. Retrieved from https://www.minneapolisfed.org/ research/sr/sr537.pdf

Kierzenkowski, R., Paini, N., Rusticelli, E., \& Zwarti, S. (2016). The economic consequences of Brexit: A taxing decision (OECD Economic Policy Paper No. 16). Retrieved from OECD website: https://www.oecd.org/economy/ The-Economic-consequences-of-Brexit-27-april-2016.pdf

Latorre, M. C. (2012). Industry restructuring in transition after the arrival of multinationals: A general equilibrium analysis with firm-type costs' differences. Post-Communist Economies, 24(4), 441-463. https://doi.org/10.1080/14631 377.2012.729304

Latorre, M. C. (2013). On the differential behaviour of national and multinational firms: A within and across sectors approach. The World Economy, 36(10), 1245-1372. https://doi.org/10.1111/twec.12100

Latorre, M. C. (2016). A CGE analysis of the impact of foreign investment and tariff reform on female and male workers in Tanzania. World Development, 77, 346-366. https://doi.org/10.1016/j.worlddev.2015.08.011

Latorre, M. C., \& Hosoe, N. (2016). The role of Japanese FDI in China. Journal of Policy Modeling, 38(2), $226-241$. https://doi.org/10.1016/j.jpolmod.2016.02.003

Latorre, M. C., Olekseyuk, Z., \& Yonezawa, H. (2018). Trade and FDI-related impacts of Brexit. Retrieved from https://ssrn.com/abstract=3168434 or https://doi.org/10.2139/ssrn.3168434

Latorre, M. C., Olekseyuk, Z., \& Yonezawa, H. (2019). Taking back control or losing it? An analysis of the possible economic impact of Brexit (PIIE Working Paper No,19-5). Retrieved from Peterson Institute for International Economics website: https://www.piie.com/system/files/documents/wp19-5.pdf

Latorre, M. C., \& Yonezawa, H. (2018). Stopped TTIP? Its potential impact on the world and the role of neglected FDI. Economic Modelling, 71, 99-120. https://doi.org/10.1016/j.econmod.2017.12.006

Liu, J., van Leeuwen, N., Thanh Vo, T., Tyers, R., \& Hertel, T. W.. (1998). Disaggregating Labor Payments by Skill Level in GTAP (GTAP Technical Paper No.11). West Lafayette, IN: Global Trade Analysis Project (GTAP), Purdue University. Retrieved from https://www.gtap.agecon.purdue.edu/resources/download/28.pdf

McDougall, R. A. (2000). A New Regional Household Demand System for GTAP. (GTAPWorking Paper No. 14). West Lafayette, IN: Purdue University. Retrieved from Global Trade Analysis Project (GTAP) website: https://www. gtap.agecon.purdue.edu/resources/res_display.asp?RecordID=404

Melitz, M., \& Redding, S. (2014). Missing gains from trade? American Economic Review: Papers \& Proceedings, 104(5), 317-321. https://doi.org/10.1257/aer.104.5.317

Melitz, M., \& Redding, S. (2015). New trade models, new welfare implications. American Economic Review, 105(3), 1105-1146. https://doi.org/10.1257/aer.20130351

Minford, P., Gupta, S., Le Mai, V. P., Mahambare, V., \& Xu, Y. (2007). Should Britain leave the EU? An economic analysis of a troubled relationship. Journal of Regional Science, 47(4), 843-845. https://doi. org/10.1111/j.1467-9787.2006.00531_3.X

Minford, P., Gupta, S., Le Mai, V. P., Mahambare, V., \& Xu, Y. (2015). Should Britain Leave the EU?: An Economic Analysis of a Troubled Relationship (2nd ed). Chentelham, UK: Edward Elgar Publishing. 
Ortiz-Valverde, G., \& Latorre, M. C. (2017). No trans-pacific partnership? Good or bad for Mexico? Journal of International Trade Law and Policy, 16(2), 106-123. https://doi.org/10.1108/JITLP-10-2016-0027

Ortiz-Valverde, G., \& Latorre, M. C. (2018). The economic impact of potential migration policies in the UK after Brexit. Contemporary Social Science, 14(2), 208-225. https://doi.org/10.1080/21582041.2018.1558278

Ottaviano, G., Pessoa, J. P., Sampson, T., \& van Reenen, J. M. (2014). Brexit or Fixit? The trade and welfare effects of leaving the European Union. CEP Policy Analysis Papers 016, Centre for Economic Performance, LSE. Retrieved from http://eprints.lse.ac.uk/57958/

Oxford Economics. (2016). Assessing the economic implications of Brexit. Executive Summary. Retrieved from https://www.oxfordeconomics.com/brexit

Peers, S. (2017). The Brexit deal is not legally binding- but politically, it's a different story altogether. The Independent. Retrieved from https://www.independent.co.uk/voices/brexit-deal-european-union-eu27-withdrawal-bill-8-decem ber-is-it-binding-a8105936.html

PricewaterhouseCoopers PwC. (2016). Leaving the EU: Implications for the UK economy. Report commissioned by The Confederation of British Industry (CBI). Retrieved from https://www.pwc.co.uk/financial-services/assets/Leavi ng-the-EU-implications-for-the-UK-FS-sector.pdf

Rybczynski, T. (1995). Factor endowment and relative commodity prices. Economica, 22(88), 336-341. https://doi. org/10.2307/2551188

Sampson, T., Dhingra, S., Ottaviano, G., \& Van Reenen, J. (2016). How 'Economists for Brexit' manage to defy the laws of gravity. LSE Business Review. Retrieved from http://eprints.lse.ac.uk/id/eprint/73791

Szary, W., \& McEnaney, C. (2018). How a migration wave drove Brexit and why it is now receding, in 8 Charts; Britons' concerns over immigration were a prime factor in their vote to leave the EU; now migrants are leaving, with mixed results for the U.K. economy. Wall Street Journal, January 8. Retrieved from https://www.wsj.com/articles/how-amigration-wave-drove-brexit-and-why-it-is-now-receding-in-8-charts-1515414601

Thomas, C. (2015). Discussion on Macroeconomic potentials of transatlantic free trade: A high-resolution perspective for Europe and the world. Economic Policy, 30(83), 529-531. https://doi.org/10.1093/epolic/eiv009

Wadsworth, J. (2015). Immigration and the UK labour market. In Election Economics: The research evidence on key issues for voters in the 2015 UK General Election (pp. 26-38). Retrieved from http://cep.lse.ac.uk/pubs/download/ ea034.pdf

Wadsworth, J. (2017a). Immigration and the UK Economy, CEP Election Analysis. Paper No' CEPEA039 in the series of background briefings on the policy issues in the June 2017 UK General Election, May. Retrieved from http://cep. 1se.ac.uk/pubs/download/ea039.pdf

Wadsworth, J. (2017b). Immigration in the UK. Technical paper, CEP Election Analysis, Paper No' CEPEA039 in the series of background briefings on the policy issues in the June 2017 UK General Election. Retrieved from http://cep. lse.ac.uk/pubs/download/ea039_technical_paper.pdf

Wadsworth, J., Dhingra, S., Ottaviano, G., \& Van Reenen, J. (2016). Brexit and the Impact of Immigration on the UK. In Brexit 2016: Policy analysis from the Centre for Economic Performance (pp. 34-53). Retrieved from https://cep. 1se.ac.uk/pubs/download/brexit08_book.pdf

Wagner, W. (2015). Discussion on non-tariff barriers, integration and the transatlantic economy. Economic Policy, 20(83), 573-574. https://doi.org/10.1093/epolic/eiv008

Zhou, J., \& Latorre, M. C. (2014a). How FDI influences the triangular trade pattern among China, East Asia and the U.S.? A CGE analysis of the sector of electronics in China. Economic Modelling, 44(S1), S77-S88. https://doi. org/10.1016/j.econmod.2014.04.030

Zhou, J., \& Latorre, M. C. (2014b). The impact of Foreign Direct Investment on the production networks between China and East Asia and the role of the U.S. and ROW as final markets. Global Economic Review: Perspectives on East Asian Economies and Industries, 43(3), 285-314. https://doi.org/10.1080/1226508X.2014.939212

How to cite this article: Ortiz Valverde G, Latorre MC. A computable general equilibrium analysis of Brexit: Barriers to trade and immigration restrictions. World Econ. 2019;00:1-24. https://doi.org/10.1111/twec.12881 


\section{APPENDIX 1}

\section{DEFINITION OF SKILLED AND UNSKILLED LABOUR CATEGORIES}

According to ILO (Liu, van Leeuwen, Thanh Vo, Tyers, \& Hertel1998), the education level can be categorised under four skill levels. As we can see in Table A1, levels 3 and 4 correspond to the highest education level (tertiary education) as well as to the highest skill occupations.

We convert the eight labour categories of GTAP database into two major categories, skilled and unskilled labour. According to Liu et al. (1998), the 3rd and 4th skill levels should go together in the skilled worker category (see table 1A, page 20). Therefore, we take the 3rd and 4th ISCO-08 skill levels as skilled labour and the 1st and 2nd ISCO-08 skill levels as unskilled.

We run a central estimate in which restrictions on migration are applied in proportion to skilled and unskilled EU migrants (labelled as 'Mix' in the paper). To this aim, we need to know the percentage of workers by education attainment level and citizenship.

No database provides the number of workers by skills and citizenship, together, to the best of our knowledge. Due to this restriction, we calculate these percentages using scattered statistics within the Labour Force Survey published by Eurostat. We have found discrepancies between this and other databases, but this seems to be the most updated information to calculate the data that we need. ${ }^{25}$

We use the 'total population from 15 to 64 years by citizenship' Eurostat (2019a), the 'percentage of population from 16 to 64 years by educational attainment level and citizenship' Eurostat (2019b) and the 'employment rates by educational attainment level and citizenship for people from 15 to 64 years' for 2017 Eurostat (2019c).

As we can see in the Table A2, 45.58\% of EU workers in the UK are skilled. This percentage is in line with the findings of Alfano et al. (2016). According to these latter authors, $47 \%$ of immigrants in the ages of 16-64 years in the UK have achieved tertiary education, and $42.6 \%$ of immigrants from European Economic Area (EEA) have high-level education.

Taking into account that $45.58 \%$ of EU workers in the UK are skilled, the impact of $1.45 \%$ by immigration restrictions can be disaggregated as a joint shock of $0.66 \%$ and $0.79 \%$ of skilled and unskilled workers, respectively.

\section{SENSITIVITY ANALYSIS}

In order to evaluate the robustness of our model, we perform a sensitivity analysis of the results obtained across our four simulations (i.e. zero tariffs, soft Brexit, hard Brexit and OECD migration scenarios). Following Harrison, Jones, Kimbell, \& Wigle (1993) and Latorre \& Hosoe (2016), we employ an unconditional systematic sensitivity analysis. This consists of re-running the four scenarios mentioned above but changing the values of three crucial elasticities: the elasticity of substitution between labour and capital, the Armington substitution between imports and domestic goods and the Armington substitution among imports by origin. Each elasticity has been varied, one by one, while keeping the rest fixed at their initial level. To simplify, this analysis focuses on the effects for GDP. The results are displayed in Table A3.

\footnotetext{
${ }^{25}$ According to Wadsworth et al. (2016), The Labour Force Survey (LFS) is the best source to evaluate immigration.
} 
TA B LE A 1 Mapping of ISCO-08 major groups to skill levels and Mapping of ISCO-08 skill level to ISCED-97 levels of education

\begin{tabular}{|c|c|c|c|}
\hline ISCO-08 major groups & ISCO-08 skill level & ISCED-97 groups & $\begin{array}{l}\text { ISCO-08 } \\
\text { skill level }\end{array}$ \\
\hline 1. Managers & $3+4$ & 6. Second stage of tertiary education & 4 \\
\hline 2. Professionals & 4 & 5a. First stage of tertiary education & 4 \\
\hline $\begin{array}{l}\text { 3. Technicians and Associate } \\
\text { Professionals }\end{array}$ & 3 & $\begin{array}{l}\text { 5b. First stage of tertiary education } \\
\text { (short medium duration) }\end{array}$ & 3 \\
\hline 4. Clerical Support Workers & 2 & $\begin{array}{l}\text { 4. Post-secondary, non-tertiary } \\
\text { education }\end{array}$ & 2 \\
\hline $\begin{array}{l}\text { 6. Skilled Agricultural, } \\
\text { Forestry and Fishery } \\
\text { Workers }\end{array}$ & 2 & 3. Upper secondary level of education & 2 \\
\hline $\begin{array}{l}\text { 7. Craft and Related Trades } \\
\text { Workers }\end{array}$ & 2 & 2. Lower secondary level of education & 2 \\
\hline $\begin{array}{l}\text { 8. Plant and Machine } \\
\text { Operators and Assemblers }\end{array}$ & 2 & 1. Primary level of education & 1 \\
\hline 9. Elementary Occupations & 1 & & \\
\hline $\begin{array}{l}\text { 10. Armed Forces } \\
\text { Occupations }\end{array}$ & $1+2+4$ & & \\
\hline
\end{tabular}

Source: ILO (2012).

TA B LE A 2 Total population and employment by educational attainment level and citizenship

\begin{tabular}{|c|c|c|c|c|c|}
\hline \multirow[b]{2}{*}{ Citizenship } & \multicolumn{5}{|c|}{ Total employment (thousands) } \\
\hline & \multicolumn{2}{|c|}{$\begin{array}{l}\text { Less than primary, primary } \\
\text { and lower secondary educa- } \\
\text { tion (levels 0-2) }\end{array}$} & $\begin{array}{l}\text { Upper secondary and post-sec- } \\
\text { ondary non-tertiary education } \\
\text { (levels } 3 \text { and } 4 \text { ) }\end{array}$ & $\begin{array}{l}\text { Tertiary educa- } \\
\text { tion (levels 5-8) }\end{array}$ & Total \\
\hline EU27 & 317 & & 967 & 1,076 & 2,360 \\
\hline Non-EU & 460 & & 1,313 & 1,795 & 3,569 \\
\hline UK & 4,487 & & 11,390 & 11,891 & 27,768 \\
\hline \multirow[t]{3}{*}{ Total } & 5,265 & & 13,670 & 14,762 & 33,697 \\
\hline & & \multicolumn{3}{|c|}{ Total employment (percentages) } & \\
\hline & & Unskilled & Skilled & Total & \\
\hline EU27 & & 54.42 & 45.58 & 100 & \\
\hline Non-EU & & 49.69 & 50.31 & 100 & \\
\hline UK & & 57.18 & 42.82 & 100 & \\
\hline
\end{tabular}

Source: Author's estimations based on Eurostat (2017) database, ILO (2012), Alfano et al. (2016).

As we can see, the results are robust to changes in the value of the elasticity of substitution between factors. We have already seen this in Table 5 because using Burfisher's (2016) values, that take a value of 12 , results on GDP are the same as with the default values. 
TABLE A3 Sensitivity analysis

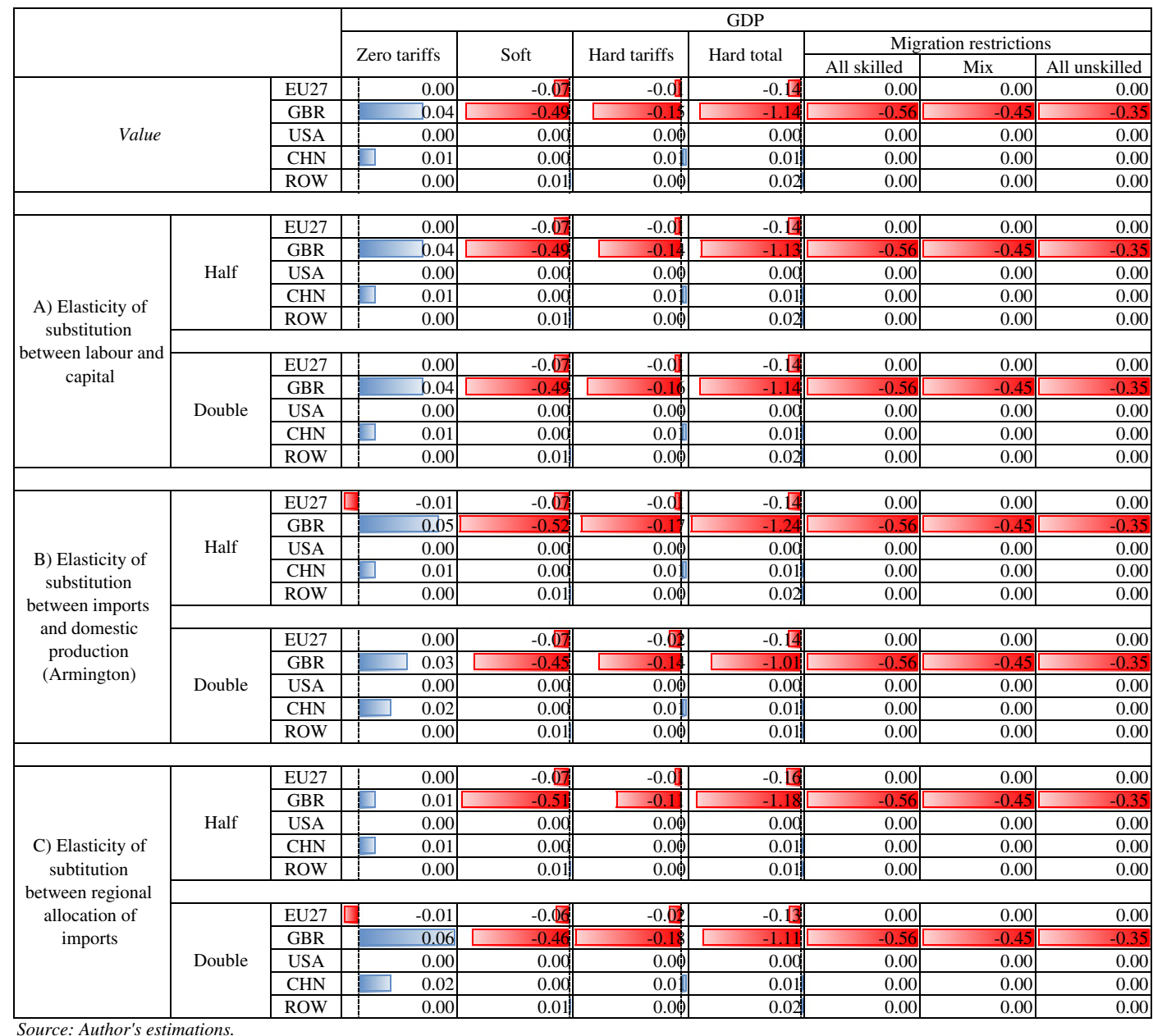

On the other hand, the Armington substitution between imported varieties and domestic goods reveals the feasibility with which consumers and producers can choose between imported varieties and domestic goods, while the Armington substitution among imports by origin shows how easy it is to change the source of the imported varieties. As we can see, in those scenarios in which we assume the increase of barriers to trade (soft and hard Brexit), larger values in both elasticities lead to lower GDP losses in the UK. In the same line, the GDP gains in the UK would be very slightly larger under the zero-tariff scenario. In other words, if consumers and producers can very flexibly substitute goods, this would enhance the GDP gains under a trade liberalisation process and reduce the losses due to restrictions to trade.

This is because with larger values of these elasticities the UK can more easily substitute the trade lost with the EU with imports from other regions or with domestic production, than with smaller values for these elasticities.

Overall, the results suggest that our previous results are very robust to different elasticities specifications. 